\title{
ANTILLA IN BRAND
}

\author{
Curaçao's geschiedenis 1939-1945 1) \\ DOOR
}

DR. JOH. HARTOG

\section{Hoofdredacteur van het Dagblad Amigoe di Curaçao}

Tegen den gekleurden ochtendhemel schoten de vlammen op van Antilla. De Duitschers hadden, vóór zij het schip verlieten en zich onvoorwaardelijk aan de Nederlandsche militairen, die het schip omsingeld hadden, overgaven, de boot in brand gestoken.

Dat was in den vroegen ochtend van 10 Mei 1940, toen de oorlogsgeschiedenis van het gebiedsdeel Curaçao zichtbaar een aanvang nam. Onzichtbaar was er door de overheid al maanden gewerkt. Men was op zijn post. Toen de morgen volop gekomen was, waren de vijanden achter slot en grendel, en in den loop van denzelfden dag werden de noodige, reeds lang voorbereide, maatregelen afgekondigd.

Antilla in brand $_{v}$ Ook andere Duitsche schepen vielen in onze handen. Antilla brandde een symbolischen brand. Antilla is het gebied der eilanden van Caraïbië, de streek van Curaçao. De groote en de kleine Antillen werden door de Duitschers in brand gestoken. De brand laaide op, kostte slachtoffers ook van onze Nederlandsche Antillen. Maar de brand werd gebluscht door de samenwerking van overheid en volk, door de oorlogsinspanning van de zes eilanden. Eilanden, die ver van het gebulder der kanonnen en het gevaar der atoombommen lagen, doch waar de grootste olieraffinaderijen haar brandstof voor de oorlogvoering leverden, waar ongeveer 130.000 Nederlanders, vijf jaren van de verbinding met het moederland verstoken, zelf den weg zochten en vonden.

De geschiedenis van deze vijf jaren wordt hier beschreven aan

1) De lezer geve zich er rekenschap van, dat aan dit opstel de schrijver in October 1945 de laatste hand legde.

$$
-193-
$$


de hand van enkele der voornaamste gebeurtenissen. Twee overzeesche gebiedsdeelen bleven vrij van den vijand, Suriname en Curaçao zijn van afhankelijk zelfstandig geworden. Misschien zijn zij nog niet volgroeid tot die wasdom, die het kenmerk van rijpheid draagt, maar de verhouding tusschen Nederland en deze gewesten heeft een ander karakter gekregen; Engeland en Frankrijk hebben bezittingen op het westelijk halfrond, Nederland heeft er gelijkberechtigde deelen.

Meer menschen van beteekenis dan ooit vroeger bezochten in deze jaren onze eilanden. Het verkeer met Curaçao werd sneller en beter, doordat naast de K.L.M., die bij het begin van den oor$\log$ nog maar alleen op Curaçao vloog, de Pan American en de Linea Aeropostal Venezolana dit gingen doen. Het levenspeil steeg door grooter wordende welvaart. Als gevolg hiervan kon meer op het gebied van kunst en cultuur gedaan worden, ondanks de groote uitgaven, die de landsverdediging vroeg. De 130.000 menschen van het gebiedsdeel Curaçao hebben veel gedaan, al blijft er plaats voor critiek.

Moreel ging het gebiedsdeel helaas achteruit. Het aantal der echtscheidingen nam toe; de komst van zoovele vreemdelingen leidde op meer dan één gebied tot verkeerde toestanden. De lectuur, die, bij gebrek aan verbinding met Nederland, in toenemende mate uit de Vereenigde Staten en Zuid-Amerika kwam, maakte het niet beter. De gemakkelijke wijze, waarop in de groot-industrie veel geld verdiend werd, benam vrijwel de geheele jongelingschap den lust om zelf de handen uit de mouwen te steken. Handenarbeid werd geschuwd, landbouw een gruwel geacht. Het werk wordt niet meer verricht om de vreugde, die het in zichzelf verschaft, maar veel zakenlieden en ook arbeiders, hier en elders zien in het geld het eenige doel van den arbeid.

Economisch heeft Curaçao een geheel andere positie gekregen. Argentinië, vóór den oorlog hier ternauwernood bekend, is zeer dichtbij gekomen. Zakenlieden vliegen op en neer. Als het moet, kan men in een etmaal in New York zijn. De verwantschap, cultureel en politiek, met de omliggende landen is Curaçao duidelijk geworden.

Het spreekt wel vanzelf, dat in dit opstel alleen de voornaamste punten der geschiedenis van Curaçao in den oorlog kunnen worden meegedeeld.

Antilla brandt! In meer dan een opzicht brandde het. Het herrezen Nederland aanschouwe het zelfstandiger en zelfbewuster geworden gebiedsdeel Curaçao. 
Met hand en tand! Reeds lang vóór Nederland, en dus Curaçao, in den oorlog werd betrokken, noopte de aanwezigheid van de olieindustrieën op Aruba en Curaçao tot maatregelen van verdediging Op 10 Mei 1940 waren alle radiotoestellen op de binnenkomende schepen reeds verzegeld. Ook het geschut, nadat onderdeelen er uit waren verwijderd. Voor geallieerde schepen werden daarom deze maatregelen achterwege gelaten. Er waren meer maatregelen voorbereid, die bij het uitbreken van een oorlog met Duitschland ten aanzien van de Duitsche schepen in de havens en buiten baaien van het gebiedsdeel aanstonds konden inwerkingtreden.

Nog in den nacht van 10 Mei 1940 konden van alle Duitsche schepen de bemanningen geïnterneerd worden, terwijlde schepen bijna onbeschadigd in onze handen vielen, ondanks dat overal maatregelen waren genomen om de schepen in brand te steken of tot zinken te brengen. Het Duitsche vrachtschip Antilla dat voor Aruba ten anker lag, werd eveneens door militairen omsingeld, maar de gezagvoerder weigerde de trap neer te laten. Onder de bedreiging, dat geweld zou worden gebruikt, liet de kapitein de scheepstrap neer; het volk ging in de booten na de buitenboordskranen te hebben open gezet en het schip in brand gestoken te hebben.

In den avond van den 10den Mei kwamen ongeveer 150 Fransche mariniers van den kruiser Jeanne d'Arc op Aruba aan wal met machinegeweren, ten einde met de Nederlandsche bezetting mee te werken.

Nadat een prijsregeling getroffen was, werd de buit gemaakte scheepsruimte benut voor de oorlogvoering der Geallieerden.

Het gebiedsdeel beschikte over een detachement eigen mariniers van ongeveer 160 man; verder was er de militaire politie, op Curaçao en Aruba samen een 160 man. Het artillerie-instructieschip Van Kinsbergen had Curaçao als basis. Er bestond een vrijwilligerskorps: VKC op Curaçao en VKA op Aruba, het eerstgenoemde in Juni 1929 door Carel N. Winkel (sjon Kai) na Urbina's overval opgericht. Op Curaçao ging de Curaçaosche Petroleum Industrie Maatschappij en op Aruba de Lago Oil Transport Company tot bescherming van het bedrijf over. Dit werd echter onvoldoende geacht, toen vliegtuigaanvallen niet denkbeeldig meer waren.

In December van het eerste oorlogsjaar kwam er een detachement artillerie van het Koninklijke Nederlandsch-Indische leger opCuraçao, dat belast werd met de bezetting der zware kustbatterijen. Tevoren waren reeds Engelsche troepen, de King's 
Shropshire Light Infantry, op Curaçao gekomen, die op Suffisant gelegerd werden, en Fransche troepen op Aruba (barakkenkamp Sabaneta); deze laatste bleven maar kort, want 6 Juli 1940 werden zij door de Cameroon Highlanders afgelost. Op St. Maarten zijn op 12 Mei 1940 ook Fransche troepen geland, die 6 weken later weer vertrokken.

Telkens lagen vreemde oorlogsschepen in de haven.

Het departement van Openbare werken moest voor onderdak dezer soldaten zorgen, want er was geen genie. Op Suffisant werd een groot kamp ingericht met bestemming om na den oorlog de oude kazerne Willem III in het Waterfort voor de eigen bezetting te vervangen.

Dienstplicht werd ingevoerd en eischte, evenals de aanvoer van nieuwe vreemde troepen, meer onderdak, waarin aanvankelijk door tijdelijke maatregelen werd voorzien.

Een practische oplossing! Naar het voorbeeld van wat op Suffisant gebeurd was, ging men, in plaats van tijdelijke gebouwen op te trekken, er bouwen, waarmee met een bestemming in den tijd na den oorlog rekening gehouden werd. Men kwam hiertoe, omdat de kosten van dergelijke gebouwen, daar alles uit het dollarland moest worden ingevoerd, ongeveer even hoog kwamen. Bovendien vergde een gebouw van beton minder scheepsruimte dan een, waarvoor hout moest worden aangevoerd, daar steen en zand hier voldoende voorhanden waren. Toen de Schotten op Aruba kwamen, werd voor hen in ongeveer 2 maanden een kamp gebouwd, dat daarna voor de Noord-Amerikaansche troepen gebruikt kon worden, en thans voor Nederlandsche troepen dient. In 1942, toen de schutterij groeide, werd op hetzelfde eiland bij Oranjestad voor 700.000 gulden een groot kamp gebouwd, dat bij de groote behoefte aan gebouwen op het zich zoo snel ontwikkellende Aruba straks een blijvende bestemming zal kunnen krijgen. Er werd daar ook een woonhuis voor officieren gebouwd, dat als gouvernements logeergebouw zal kunnen dienst doen. Het verblijf der onderofficieren is bestemd voor kantoor der belastingen; de militaire cellen, naast het politiebureau gelegen, kunnen in het tekort aan gevangenisruimte voorzien; de cantine wordt straks vergader- en bioscoopzaal; de slaapzalen kunnen straks tot pakhuizen worden ingericht. Het is een practische gedachte geweest, om op deze wijze van den nood een deugd te maken.

De Noord-Amerikanen komen! Toen de Vereenigde Staten in den oorlog betrokken werden, veranderde de algemeene toestand 
in het Caraïbisch gebied. Het werd in korten tijd in zekeren zin onder Noord-Amerikaansch oppertoezicht gebracht. 11 Februari 1942 kwamen hier Amerikaansche troepen, die - in afwisselende sterkte - gebleven zijn. Drie dagen na hun komst vertrokken de Engelschen. De Amerikaansche luchtmacht vestigde zich op Hato. Hier was groote verandering noodig. De vliegvelden waren te klein voor de zware bommenwerpers. Eenige startbanen moesten verhard worden en tot 1600 meter verlengd, alles in korten tijd. De ramen van de passagiersvliegtuigen - Hato bleef burgerluchthaven - werden, lang vóór zij Curaçao bereikt hadden, afgeschermd, zoodat geen kier overbleef, die uitzicht gaf op het oorlogsgedoe. Naast Hato kwamen ruime gecamoufleerde parkeerplaatsen, waar tientallen kleine en groote vliegtuigen stonden, die niemand mocht zien. Een groot terrein in den omtrek was verboden gebied, met prikkeldraad afgezet. Ook de grot van Hato was niet toegankelijk, omdat er een opslagplaats van munitie in was aangebracht; achter de grot was een benzinedepot. Een NoordAmerikaansche schildwacht bewaakte den toegang tot Hato.

Op Aruba werd het vliegveld Dakota verlengd, waartoe de straatweg naar San Nicolaas moest worden omgelegd langs de zee. Het bij deze gelegenheid opgetrokken nieuwe stationsgebouw is nu al bijna weer te klein, zoo snel neemt het luchtverkeer toe.

Op Bonaire kwam een nieuw vliegveld tusschen Kralendijk en de zoutpannen tot stand met een mooie, verharde baan van 1000 meter. Ook St. Maarten kreeg een vliegveld, het Prinses-Julianavliegveld, een eind voorbij Simpsonsbaai, dat ook groote dienst aan de burgerluchtvaart bewees.

Noord-Amerikaansche mariniers bouwden een marinebasis op Parera (Curaçao), waar het een druk verkeer van oorlogsschepen werd.

De gouvernementssecretarie verhuisde uit het fort Amsterdam naar de Handelskade, en in haar oude gebouw kwam beneden het commando der Nederlandsche strijdkrachten en boven dat der Amerikanen, dat onder een schout-bij-nacht of commandant van den breeden wimpel kwam te staan, die den titel Commander of All Forces Aruba and Curaçao (CAFAC) kwam te staan.

De Amerikaansche infanterie lag op Suffisant; de artillerie kreeg kampen aan St. Michielsbaai, Domi (Habaai) en elders, alles afgezet met hooge prikkeldraad- en andere versperringen. MP's (military police) en SP's (ship's police) liepen in khaki en witte uniformen door de stad om orde en tucht onder de vreemde manschappen te bewaren, en zij wisten de sympathie der bevolking 
te winnen; in meer dan een woning werden de Amerikanen vriendelijk ontvangen.

Daar komen de schutters! Curaçao ging ook een eigen krijgsmacht opbouwen, de schutterij, in art. 155 van de Curaçaosche staatsregeling voorzien, ,in geval Curaçao door een buiten- of binnenlandsche vijand bedreigd wordt" en ook ,,in tijd van vrede, tot bewaring der inwendige rust." De eerste lichting kwam in December 1940 op, van Curaçao, Aruba en Bonaire. In het geheel zijn er 7 jaarklassen in 9 lichtingen opgekomen. De grootste sterkte was ongeveer 3000 man, wat bijzonder hoog mag worden genoemd op een geheel van 130.000 inwoners, ongeveer $2,3 \%$; in Nederland was ongeveer $4,4 \%$ onder de wapenen, maar een kleine maatschappij wordt door onttrekking van een groot aantal personen eerder ontwricht dan een grootere. Deze ontwrichting moest in Curaçao met het oog op de oorlogsindustrie vóór alles voorkomen worden. En er waren meer mannen noodig. Er kwam een transportcolonne van ongeveer 100 man. De luchtbescherming eischte op Aruba een 350, op Curaçao 650 man. Er werd een burgerwacht opgericht met 125 man op Aruba en 325 op Curaçao, die 's avonds en Zondags oefenden en daarbij hun gewone dagtaak bleven vervullen. Kantoorbedienden en rechters, notarissen en ambtenaren, loopjongens, menschen uit alle kringen der maatschappij maakten deel uit van de burgerwacht en verrichten in uniform met het geweer op schouder en de helm op het hoofd hun zware diensten. In April 1942, enkele maanden na Pearl Harbour, toen het duikbootgevaar in de Caraïbische zee groot was, werd de burgerwacht opgeroepen. Er waren drie groepen: de hoekmeters, die op de zijposten van de kustbatterijen zaten als waarnemers, de Bupol, burgerwacht-politie, die hulpdiensten aan de politie verleende, en zij, die de belangrijke gebouwen bewaakten. In den loop van 1944 kon de Burgerwacht gaan rusten, en met 1 Jan. 1945 is zij opgeheven.

Van de schutterij schreef de luitenant ter zee H. A. Corsten destijds in de Amigoe: „Thans dienen enige duizenden inwoners van deze eilanden in de schutterij, en, hoewel de Curaçaoënaars van nature gans niet militair zijn aangelegd, hebben zij zich ontwikkeld tot bekwame soldaten, die de toets der vergelijking met hun soortgenoten in de Caraïbische wateren rustig kunnen doorstaan.

Voorts kan met voldoening worden geconstateerd, dat de $\mathrm{Cu}-$ raçaose schutterij een belangrijk aandeel heeft gehad in de bevei- 
liging van eigen bodem en bewaking van de op deze eilanden gevestigde, voor de oorlogvoering zo belangrijke oliemaatschappijen

Het ontbreken van werkelijke krijgsverrichtingen maakte het uiteraard niet eenvoudig de Curaçaose Weermacht gedurende de vijf lange jaren van de oorlog in Europa steeds te overtuigen van de noodzaak waakzaam en paraat te blijven.

In het algemeen gesproken, heeft de Curaçaose schutter evenwel goed gediend en de zo eentonige bewakingstaak werd naar behoren verricht."

In deze schutterij, waarin vooral de zonen des lands dienden, vond men ook Surinamers en Europeesch-Nederlandsche dienstplichtigen, blank en zwart dooreen.

De reserve-officieren kwamen in werkelijken dienst. Ten slotte waren er niet meer dan twee beroepsofficieren bij de landmacht, ongeacht hen, die bij de schutterij tot dien rang opklommen

Er was een groote verscheidenheid van uniformen. Behalve die der geällieerde troepen zag men die der in Zuid-Afrika en Canada wonende Nederlanders, die hun Nederlanderschap niet verloren hadden, en die van het Nederlandsch-Indische leger.

De Koninklijke Marine in actie! De Van Kinsbergen deed haar kruistochten en heeft ook metterdaad aan den strijd deelgenomen.

Eenige adelborsten hadden in Mei 1940 met een officier Engeland kunnen bereiken met het in 1904 door de Koningin uitgereikte vaandel. Dit vaandel kwam via Oost-Indië in 1942 te Willemstad, en op den verjaardag van prinses Juliana, 30 April, van dat jaar legden 11 adelborsten daarop den eed af. Nimmer tevoren had men op Curaçao zulk een plechtigheid bijgewoond.

In den loop van 1940 werd Hr. Ms. Jan van Brakel hierheen gezonden. Eenige Noorsche walvischvaarders werden op Curaçao verbouwd tot goed bruikbare patrouillevaartuigen voor de Koninklijke marine. Verder kwamen er mijnenvegers uit Engeland, en in 1942 kwam de in de Vereenigde staten gebouwde Queen Wilhelmina. Motortorpedobooten, oorspronkelijk voor Nederlandsch-Indië bestemd, kwamen hier juist op het oogenblik, toen de duikbootoorlog in de West het hoogtepunt had bereikt.

Het grootere materieel van de Koninklijke marine werd, met geallieerde oorlogsbodems, gebruikt om escorte te verleenen aan de koopvaardij; onze kustpatrouillevaartuigen en torpedomotorbooten patrouilleerden langs de kusten van Curaçao en Aruba. De duikbootoorlog maakte meer en meer operatief optreden van marine-eenheden van de haven van Curaçao uit noodig. Naast die der Amerikanen werd een eigen marinebasis gebouwd. 
Twee marinebases op Parera. De bouw dezer laatste, in 1942 begonnen, was in 1944 gereed. Met inbegrip van de inventaris kwam alles op f.2.500.000.-. Hoog op een heuveltop ligt het officiersverblijf voor 20 officieren. Verder is er een verblijf met tuin voor de onderofficieren, dat lager ligt, en een kwartier voor de manschappen. Het ligt in de bedoeling de Nederlandsche basis met een scheepshelling voor motortorpedobooten, werkplaatsen, opslagplaatsen enz. te laten bestaan, terwijl de minder degelijk gebouwde Amerikaansche marinebasis zal verdwijnen.

De n.v. Combinatie Pletterij Nederhorst is zich in den oorlog gaan toeleggen op scheepsherstellingen en bewapening van koopvaardijschepen. In de Versalibaai richtte zij een werkplaats in en een scheepshelling voor kleine scheepsbouw.

Netten vóór de havens. Aan den ingang van de St. Annabaai kwam een zwaar net te hangen om de duikbooten het binnenkomen te beletten. Telkens als de brug open ging, werd het net opzij gedraaid. Ook in de Caracasbaai en de Bullenbaai hing een net, evenals vóór de haven van Aruba.

Eenige nieuwe gebouwtjes langs de St.Annabaai waren ingericht voor controleering en verbetering van de demagnetiseeringsinstallaties op de voorbijvarende schepen.

„Caribbean Sea Frontier.' In theorie is volgens art. 30 van de Curaçaosche staatsregeling de gouverneur opperbevelhebber van leger en vloot, in feite is dit de Algemeene militaire commandant, een vlag- of hoofdofficier der Koninklijke marine, een schout bij nacht of kapitein ter zee.

$\mathrm{Na}$ Pearl Harbour zetelde op Puerto Rico de Commander Caribbean Sea Frontier, die in 1942 het strategisch en tactisch bevel over alle militaire operaties, ook der Nederlandsche troepen, kreeg. De Algemeene militaire commandant, als chef-staf ingeschakeld, behield zijn bevoegdheden, maar werd verantwoording schuldig, niet meer aan den gouverneur van Curaçao, maar aan den bovengenoemden CAFAC.

De lasten van den oorlog. Zonder klachten droeg de bevolking over het algemeen de zware lasten van den oorlog. Met de geldelijke lasten was dit minder moeilijk dan met die, welke op het economisch leven rustten. Er waren 250 van de 7100 arbeiders der C. P. I. M. onder de wapenen, en naar gelang de bedrijven minder werkkrachten telden, waren de bezwaren tot afstand van personeel grooter. Achteraf bezien, is het een wonder, dat alles nog zoo geloopen is. 
In de eerste plaats werden de volgende kosten van landsverdediging ten laste van Curaçao gebracht:

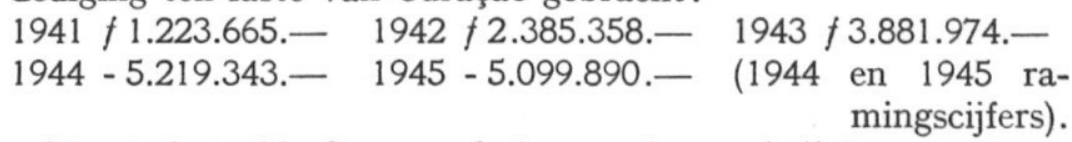

Voorts betaalde Curaçao de kosten der verdediging van Curaçao, die volgens de staatsregeling ten laste van het rijk in Europa hadden moeten komen, te weten in 1940300.000 gulden, en in de volgende jaren telkens 240.000 gulden, verder bijdragen in de kosten der algemeene oorlogvoering, nl. in 1940800.000 gulden, 1941 1.370.000, 1942 2.490.000, 19432.000 .000 gulden, terwijl de ramingscijfers voor de volgende jaren zijn geweest 924.025 en 659.834 gulden. Onder de fiscale maatregelen, ter bereiking van dit doel genomen, komen voor de heffing van opcenten op de inkomstenbelasting, winstbelasting, invoerrechten, accijns op gedistilleerd en loodsgelden.

De kusten verontrust! In den nacht van 16 Februari 1942 schoten de Duitschers hun eerste torpedo op het westelijk halfrond af. Het projectiel kwam op Aruba terecht. Enkele tankschepen in de haven van San Nicolas en op de reede bij Druif, een vijftal: de Druif, de Nicolaas, de Oranjestad, de Tia Juana en de Pedernales, werden in brand geschoten of getorpedeerd. Een paar uur later werd een tankschip van de Curaçaosche Scheepvaartmaatschappij vlak vóór de haven van Curaçao getorpedeerd. Den volgenden dag lieten bij demonteering van een vijandelijke torpedo op de kust van Aruba een officier, een onderofficier en eenige manschappen het leven. Uit San Nicolaas (Aruba) begon de bevolking angstig weg te trekken naar Santa Cruz.

Het was een begin. Van tijd tot tijd deden de Duitsche duikbooten nieuwe aanvallen op onze kusten. 12 Nov. 1942 werd vlak vóór de Curaçaosche kust een Noord-Amerikaansche torpedojager, de Erie, getorpedeerd. Door de bemanning kon het afdrijvende schip halverwege tusschen Riffort en Piscaderabaai op het strand gezet worden, een vlammen-schouwspel tegen den nog donkeren ochtendhemel. Met veel geraas vloog het munitiemagazijn aan boord in de lucht. Het later naar binnen gesleepte geraamte zonk eerst in het Schottegat, maar kon gelicht en nog hersteld worden.

Een aanval op de kustbatterij van Bullenbaai in April 1942 werd door de waakzaamheid van den korporaal M. van Niel afgeslagen. Deze korporaal werd door den gouverneur in persoon gehuldigd. 
Op St. Maarten kwamen in Sept. 194215 schipbreukelingen van een Engelsch schip aan wal; later nog een 24 van een Nederlandsch schip, en weer een anderen keer 49 van een Amerikaansch schip, dat bij Anguilla in den grond was geboord. Op St. Eustatius landden de overlevenden van een verongelukt vliegtuig. De reddingsboot van Curaçao moest verscheidene malen diep in den nacht zee kiezen om hulp te bieden, tot bij Westpunt toe.

Waar bleek wat de toenmalige minister van Marine lt. admiraal Furnster in Sept. 1942 bij zijn bezoek aan ons eiland tot de pers zei: „Curaçao is een uitvalspoort om de zeewegen in de Caraïbische zee open te houden en om het duikbootgevaar te bestrijden. Mede dank zij Curaçao zijn deze zeewegen open gebleven en is het duikbootgevaar bezworen. Wel is waar ten koste van menschenlevens, maar de Vereenigde Volken zijn erdoor gebaat.

Beveiligingsmaatregelen. Reeds in 1939 is de luchtbeschermingsdienst ingericht. De adjudant van den gouverneur, luitenant E. C. J. M. van den Laarschot was er het hoofd van. 150.000 gulden werden voor dit doel beschikbaar gesteld. Door lezingen werd voorlichting verstrekt, en een landsverordering werd, toen de oorlog behandeling in de Staten niet meer mogelijk maakte, spoedshalve bij besluit afgekondigd, en later als landsverordening bekrachtigd.

Het eiland en het stadsdistrict werden in rayons verdeeld, waarbij er rekening mee werd gehouden, dat de schipbrug bij een bombardement zou worden opengedraaid om brandende schepen naar buiten te kunnen zenden. Een hoofdkwartier werd even buiten de stad ingericht.

Op Aruba en Curaçao - Bonaire kreeg later alleen verduistering - bestond de luchtbeschermingsdienst uit de volgende onderdeelen: een geneeskundige dienst met eerste-hulp-posten, noodambulances, noodhospitalen en transportcolonnes; een politiedienst: de Lupo (luchtbeschermingspolitie) en de Bupol (burgerwacht-politie); de brandweer, aanzienlijk uitgebreid. Bij een proef bleek hoe goed alles werkte. Nog waren er opruimingsploegen en takken voor telefoon, electriciteit en waterleiding, godsdienstige verzorging, sirenes en schuilkelders; een veterinaire dienst zou zorgen voor het vee. Afzonderlijke ploegen bewaakten de haven.

Reeds 23 Oct. 1939 was er een verduisteringsoefening gehouden. In Mei 1940 werd de verduistering afgekondigd, gelukkig maar voor kort. In Dec. 1941 was er met het oog op het dreigende duikbootgevaar weer verduistering, en de met den aanval van 16 Febr. 
1942 afgekondigde verduistering bleef tot Oct. 1943 van kracht, een groot ongerief bij de vroeg en snel invallende duisternis. Alle afkondigingen werden aangeplakt in het Nederlandsch, Spaansch, Engelsch en Papiamentsch, en in de Chinezenwijk in Punda nog eens in het Chineesch. Bij de grootste oefening, in 1943, werd 's nachts om 2 uur alarm gemaakt; branden werden gesticht en barricades opgeworpen.

Op de raffinaderij-terreinen zorgden C. P. I. M. en Lago voor eigen schuilplaatsen, hulpposten, brandweer, noodhospitalen enz.

Als merkwaardigheid mag vermeld worden, dat een rapport over den Curaçaoschen luchtbeschermingsdienst op Aruba en Curaçao naar Suriname en ook naar Australië gegaan is en gediend heeft om daar op denzelfden grondslag dergelijke diensten in te richten. De kosten der propaganda voor dezen dienst werden voor een goed deel gedragen door de Curaçaosche vereeniging voor luchtbescherming, die, in April 1939 opgericht, een maandblad Luchtbescherming uitgaf, dat 850 betalende inteekenaren had voorts gaf deze vereeniging drie vlugschriften uit, ongeacht de ,wenken", in oplagen van 12000 stuks verspreid. Leergangen werden gegeven, een bibliotheek ingericht en tentoonstellingen gehouden, van welke laatste een rondreis bij de scholen. Verder werd propaganda gemaakt door pers en radio. Eerst met Nederland, daarna met de Oost, en ten slotte met Engeland en Amerika, werd voeling gehouden.

In het begin van 1942 werd om het duikbootgevaar de VanSlobbe-boulevard langs de zee des avonds voor rijverkeer gesloten; ook de schipbrug mocht niet met verlichting bereden worden. Onbewoonde panden moesten 's nachts bewaakt worden; later was het voldoende, als op de deur een aanduiding was geplakt, waar de sleutel beschikbaar was. 31 Augustus werd deze bepaling opgeheven, zeer onverwacht.

Allerlei maatregelen ter beveiliging van Curaçao als een der belangrijkste afscheephavens van olie ter wereld werden noode aanvaard, omdat het nut er niet van werd ingezien. Er was te weinig aanraking tusschen militaire overheid en bevolking, en, hoewel van sabotage dezer maatregelen weinig of niet sprake is geweest, heerschte soms wel eenig misnoegen over de als oekasen uitgevaardigde voorschriften.

Als rechtstreeks voor oorlogsdoeleinden een beroep op de bevolking gedaan werd, was deze tot geven bereid. Het Prins Bernhardfonds op Curaçao en het Wilhelminafonds op Aruba, die gelden voor wapenaanmaak inzamelden, waren een succes, en het- 
zelfde kan gezegd worden van den bloedtransfusiedienst. Ook in de schutterij deden zich nagenoeg geen moeilijkheden voor ondanks de demoraliseerende invloeden, waaraan deze bloodstond.

Toen in den loop van 1943 aan de Staten gevraagd werd, wat zij dachten van het overzee sturen der Curaçaosche schutters, werd een antwoord ontvangen, dat op het eerste gezicht „,neen” zeide, maar even goed als ,,ja" kon worden uitgelegd. (Men zie het advies in de Amigoe di Curaçao van 24 Sept. 1943). De openbare meening stond beslist afwijzend tegenover deze zaak.

Vrijwilligers echter gingen. Zoo vertrok in de tweede helft van 1944 een $V$ rijwilligers $H$ ulp Korps naar Engeland om te gaan deelnemen aan de bevrijding van Nederland. Hollandsche, Surinaamsche en Curaçaosche meisjes, leden van dit korps, had men tevoren kunnen zien oefenen met de zwaarste legertrucks en tegen hindernissen, zooals het oorlogsterrein zou kunnen bieden. Volgens de berichten hebben zij bij de overstroomingen in Zeeland zeer goede diensten bewezen.

In Dec. 1944 trok een Roode-kruisploeg van 30 man onder P. Rietkerk naar de Oost. Toen Balikpapan bevrijd werd, werden zij in de telegrammen genoemd.

Naar Ned. Indië trokken ook twee eenheden damesrecruten van het Vrouwenkorps van het Kon. Ned. Indische leger.

Het zoogenaamde "Oliebataljon" was een groep personeel van de C.P. I. M., die in militair verband over Australië naar OostIndië ging, om de heroverde olie-industrie opgang te helpen.

Verder gingen als vrijwilligers dokters, politiemannen enz. Gedurende den oorlog kwamen vele buitenlandsche oorlogsbodems de haven binnen. Vooral de binnenkomst van de groote vliegdekschepen trok de aandacht. De St. Annabaai lag niet bepaald gunstig voor de militaire geheimzinnigheid. Clubs gaven feesten; de zeemanshuizen en restaurants waren druk bezocht. De Van Kinsbergen kwam na lange en bange tochten; de kinderen van het St. Martinusgesticht stonden langs de baai en de gouverneur verscheen, salueerend, voor het venster van het gouvernementshuis. Bijna wekelijks kwamen Britsche en Noord-Amerikaansche schepen; een enkele maal Zuid-Amerikaansche, van Columbia en Peru. De consuls richten feesten aan.

In het geheel heeft het Curaçaosche commando niet meer dan 9 communiqué's over vijandelijkheden in de Curaçaosche wateren behoeven te geven.

Toen de Duitschers verslagen waren, ging de liquidatie der oorlogsmaatregelen verrassend snel. 20 Juni 1945 werd de havenbe- 
waking opgeheven, 30 Juni verdween de staat van beleg; kort na de capitulatie van Japan nam de censuur op post, telegraaf en telefoon een einde.

De schutters blijven. Enkele dagen vóór de bevrijding deelde de gouverneur aan de Staten mee, dat in de oorlogsjaren de onmisbaarheid van de schutterij was gebleken. In Juli 1945 werd besloten 850 van de 3000 man (7 jaarklassen) naar huis te zenden, maar de dienstplicht zou blijven bestaan. De vaststelling van de vredessterkte zou in overleg met de Staten worden vastgesteld; met deze toezegging werden de bezwaren der Staten tegen den voortgezetten dienstplicht ondervangen.

De bevolking heeft ingelost de woorden van gouverneur Wouters bij diens mededeeling van den overval van Nederland: „Het hier gevestigd gezag is besloten en in staat op den bestaanden voet het bewind te blijven voeren en te blijven waken over het rechtsgebied zoo te land als ter zee."

Ontspanning. Ten dienste der Noord-Amerikanen werd het Bargebad aan het Rif verbouwd tot een U(nited) S(ervice) O(rganisation). Het bad, waarin men toch niet meer kon zwemmen vanwege olie, teer en andere dingen, die zoo dicht bij den havenmond, het water verontreinigden, werd afgesloten. Jan Thiel werd voor het publiek eveneens gesloten, maar voor de Amerikanen opengesteld. Ook op Aruba kregen de Amerikanen hun club.

Voor de schutters werd naar het Amerikaansche voorbeeld een dienst $\mathrm{O}$ (ntwikkeling) en $\mathrm{O}$ (ntspanning) in het leven geroepen. Enkele cabaretavonden werden gegeven, op Westpunt een vacantiehuisje ingericht, terwijl St. Michielsbaai hun zwembad werd.

De Roomsch-Katholieke militaire vereeniging, die vóór den oorlog al tweemaal een eigen tehuis had gehad, was in 1939 bij de uitbreiding van de gewapende macht haar werk weer begonnen. Onder leiding van pater-aalmoezenier A. v. d. Meer O. P., kapitein Th. van Erp en luitenant Van de Laarschot werd in Februari 1940 reeds een huis op Pietermaai geopend. Een jaar lang is er op Suffisant nog een tehuis voor de schutters geweest.

Voor Koningin en Vaderland. De oorlog vroeg offers: de torpedeering van tankschepen eischte tientallen schepelingen, inwoners van het gebiedsdeel Curaçao. Ook op andere wijze vielen enkelen. In Nederland zijn omgekomen Boy Escury, een Arubaan, die lid van de ,ondergrondsche" was, en George Maduro, die zich in de Meidagen heldhaftig gedroeg en later door verraad in handen 
der Duitschers viel, die hem naar een concentratiekamp in Duitschland brachten, waar hij overleed. Escury werd in Juli 1944 gegrepen, toen hij met een belangrijke opdracht naar Rotterdam was gegaan; eenige maanden later werd hij gefusilleerd. Over de heldendaden van Maduro heeft de Militaire Spectator een uitvoerig verslag gegeven, dat de Curaçaosche bladen gaarne overgenomen hebben.

Het gouvernement voert oorlog. Fort Amsterdam werd scherper bewaakt dan voorheen. Telefooncentrale, de vliegvelden, de oorlogsbedrijven, stonden onder voortdurend toezicht. De kustbewaking werd uitgeoefend door een speciaal corps, dat voornamelijk uit technisch personeel van de C. P. I. M. bestond, en verder uit particulieren. In het fort Amsterdam was het stafbureau in de oude gouvernementssecretarie. In het Route-bureau, waar men af en toe de scheepskapiteins zag binnengaan, werden de convooiroutes uitgezet, en van het balkon af werd het binnen varen der convooien geregeld.

De afkondiging van den staat van beleg bij het uitbreken van den oorlog werd door een reeks maatregelen gevolgd. Het Militair Gezag werd ingesteld; de procureur-generaal kreeg de bevoegdheid ter handhaving van de openbare orde wettelijke voorschriften terzijde te stellen (huiszoeking, pers-, telefoon-, post- en telegraafcensuur, sluiting van de grenzen, zelfs voor Nederlanders behalve familieleden, geruchtenbestrijding enz.). Sommige bedrijven werden tot verplichte bedrijven verklaard, als van vitaal belang vóór de oorlogvoering.

Slechts twee conflicten van beteekenis hebben zich in den loop der jaren voorgedaan, het zg. CSM-conflict en de Chinezenkwestie.

De Curaçaosche Scheepvaartmaatschappij, die de tankvaart op het meer van Maracaibo uitoefent, werd in Febr. 1942 het eerste verplichte bedrijf. Betere voorzieningen eischend, weigerden enkele officieren dienst. Zij werden in een kamp voor onwillige zeelieden opgesloten. De gemoederen waren bewogen, en pijnlijk deed het aan, dat door de preventieve censuur niet werd gedoogd, dat van de zijde der officieren ingezonden stukken in de pers werden opgenomen, noch dat de zaak van redactiewege werd besproken, terwijl de censuur enkele stukken van de zijde der CSM wel doorliet. De Amigoe di Curaçao werd daarop wegens vermeende overtreding der censuurvoorschriften geschorst voor eenige lagen. Het conflict had een komisch einde, want lang daarna besliste de rechter, dat de zeelieden ten onrechte in het kamp waren geplaatst. De Staten namen een slappe houding aan in deze 
zaak. Het gevolg was de oprichting van de Centrale voor koopvaardijofficieren.

De opsluiting der Chineezen had een ernstiger slot. Ongeveer tegelijkertijd met de officieren staakten een 250 Chineezen van de tankvloot, ook om betere voorwaarden te krijgen.Achttien woordvoerders werden opgesloten in het Portugeezen-kamp. Het aantal liep op tot een 300. Het kamp werd bewaakt door den bewakingsdienst der C. P. I. M. Wie de order tot opsluiting had gegeven kon niet blijken: de Algemeene militaire commandant, het Openbaar ministerie, de Vreemdelingenpolitie beweerden eenstemmig, dat zij erbuiten stonden. Feitelijk was het zoo gegaan, dat de Chineezen zich verzameld hadden vóór het politiebureau, $\mathrm{e}$ de aanzegging om te gaan varen geroepen hadden: Sluit ons dan maar in. En zoo was het geschied. Dus op eigen verzoek. Toen zij op 9 Apr. 1942 vroegen om vrijgelaten te worden, werd dit geweigerd. Op 19 April ontstond daarop een botsing met de bewakers, die zich verdedigden met hun vuurwapenen, en daarbij vielen 12 dooden en tientallen gewonden, van welke nog drie stierven. In Juni d.a.v. bezocht de consul-generaal Pei Weih Lui op Havanna ons eiland om de zaak te onderzoeken. Hij beloofde een rapport te zullen opstellen en vroeg de vrijlating van 413 Chineezen. In December 1942 deelde hij mee, dat het conflict was bijgelegd. Dr. Zaubeh Sje stichtte ongeveer een jaar later op Curaçao het eerste Chineesche consulaat, tevens dienende voor Aruba en Suriname. Er waren toen op Curaçao 500, op Aruba 200 en in Suriname 2000 Chinezen.

Verschillende maatregelen. Reeds in 1939 zorgde de Voedselvoorzieningscommissie voor een voorraad levensmiddelen van ten minste 1 maand. Het gouvernement hield 80.000 gulden beschikbaar voor verschotten ten dienste van het aanleggen van voorraden tarwemeel, de zoogen. buffer-stock. Ook nog in dat jaar werd een besluit afgekondigd, dat opvordering van goederen ten dienste van de landsverdediging of volkshuishouding mogelijk maakte. Het Inventarisatiebesluit verplichtte de handelaren op te geven aard, hoeveelheid en inkoopsprijs van hun voorraad of bestelde levensmiddelen, huishoudelijke artikelen enz. Er kwam een uitvoerverbod van deze goederen. Het Prijsopdrijvings- en Hamsterbesluit werd noodig, toen, vooral in 1942, de aanvoer door gebrek aan scheepsruimte verminderde; maximum-prijzen werden vastgesteld.

Tengevolge van deze maatregelen en dank zij de toewijding van hen, die met de uitvoering belast waren, is er nooit een tekort 
geweest. Alleen op de bovenwindsche eilanden heeft men eenigen tijd krap gezeten, maar hierin is voorzien kunnen worden.

In Juli 1942 kwam een Bouwverbod, dat behalve nieuwbouw herstellingen van gebouwen zonder vergunning verbood.De bedoeling was werken voor de landsverdediging te laten voorgaan Aannemers op Aruba en Curaçao hebben met deze laatste bouwwerken goede zaken gemaakt.

Het Schrijt- en kantoormachinebesluit verbood deze machines (die voor luchtkoeling inbegrepen) te verkoopen, aan te bieden, af te leveren en te vernietigen; er was namelijk gebrek aan deze artikelen.

In het tekort aan telefoonstellen kon niet worden voorzien.

Gezagvoerders mochten instructies van hun directies om te varen slechts opvolgen met toestemming van den gouverneur.

10 Mei 1940 nam de Curaçaosche bank op verzoek der andere banken de leiding in de financieele maatregelen. Reeds dadelijk stond men voor het monetaire vraagstuk, toen de regeling tusschen de Nederlandsche en de Engelsche regeeringen over pond en gulden bekend werd. De handel in Curaçao moest zich geheel op Noord-Amerika gaan instellen, en men vreesde nu een tekort aan dollars en een overvloed van ponden. Monetaire missies trokken heen en weer tusschen Curaçao, New-York en Londen. Men mag voldoening uitspreken over het beleid der Curaçaosche administrateurs en financiën, eerst $\mathrm{mr}$. H. I. Franke en later $\mathrm{mr}$. H. J. M. Hoogeveen. De Curaçaosche gulden is thans voor $113 \%$ met goud gedekt, terwijl de Nederlandsche gulden volgens den eersten weekstaat van de Ned. bank nog maar een gouddekking van $17 \%$ heeft.

Verschillende instellingen kwamen onder leiding van de Administratie van financiën te staan: de Deviezencommissie, die tot taak heeft de bevordering van het beschikbaar komen van voor de instandhouding der volkshuishouding noodige deviezen en de juiste besteding daarvan; de reeds genoemde Voedselvoorzieningscommissie en de Distributiecommissie.

Deze laatste bereidde een stelsel voor ten aanzien van die levensmiddelen, welke niet in voldoende mate konden worden ingevoerd. De eenige distributie, die in de practijk noodig is gebleken, is die van ..... benzine geweest, echter niet omdat er een tekort was, maar omdat er te veel was: de menschen maakten te gemakkelijk van hun auto's gebruik, en daardoor ontstond bandenschaarschte. Een Bandencommissie zorgde voor een doel- 
matige verdeeling van banden, nadat de ontduiking der benzinedistributie tot intrekking daarvan had geleid.

Het Bureau voor Economische zaken stelde maximumprijzen en maximumwinstpercentages voor verschillende goederen vast om prijsstijgingen te voorkomen. Een Huurcommissie zorgde voor nakoming van de bepalingen op woninghuren; er was een groot tekort aan woningen.

De Inkoopcentrale Curaçao (IN-Cu) had tot taak te bevorderen, dat goederen, die particulieren niet of moeilijk zonder tusschenkomst van de overheid uit het buitenland konden betrekken, naar behoefte voor Curaçao verkrijgbaar werden. Ook voor noodzakelijke inkoopen van andere goederen verleende dit bureau medewerking.

De Curaçaosche Commissie Regeling Rechtsverkeer in Oorlogstijd oefende alle rechten uit, voortvloeiende uit verbintenissen, waarbij de vijand, een vijandelijk onderdaan of een zich in vijandelijk gebied bevindend persoon partij was. Dr. Sylvain I. Groen had hier de leiding. 11 Mei 1940 kon aanstonds de tevoren ontworpen Curaçaosche regeling Rechtsverkeer in Oorlogstijd in werking treden. In Publicatieblad 1944 no. 153 vindt men de volledige regeling, zooals zij in den loop der jaren geworden is. Zonder toestemming van de Commissie Rechtsverkeer mochten geen zaken gedaan worden met vijandelijke onderdanen en firma's, ook niet met in door den vijand bezet gebied zich bevindende zaken. Het beheer over de vermogens van vijanden in Curaçao was in handen dezer commissie; hiertoe behoorden nalatenschappen, meubilair enz. Van hetgeen verkocht moest worden, krijgen de rechthebbenden nu, na den oorlog, de opbrengst uitgekeerd.

Tot het werk dezer commissie behoorde ook de zetelverplaatsingen van ondernemingen ingevolge de wet van $26 \mathrm{Apr} .1940$ Staatsblad no. 200, de laatste vóór den oorlog afgekondigde wet. Ongeveer 165 naamlooze vennootschappen hebben uit Nederland en Nederlandsch-Indië haar zetel naar Curaçao verplaatst; het waren vooral vennootschappen op het gebied van handel en nijverheid, assurantiemaatschappijen, en enkele vereenigingen met een onstoffelijk doel als de beide Jounalistenorganisaties. Op deze wijze konden vele Nederlandsche zaken haar bedrijf voortzetten en haar markten behouden; nieuwe markten werden veroveid. De Curaçaosche fiscus heeft geen voordeel van deze zetelverplaatsingen gehad, anders dan door het Handelsregister, dat echter te laat tot stand kwam. Voor zoover bekend, werden 
geen naamlooze vennootschappen naar een der andere eilanden overgeplaatst.

De levensverzekeringen gingen voort. Door de bezetting van Nederland geraakten velen, die zich daar verzekerd hadden in moeilijkheden. In Indië heeft men opgericht de stichting Oostindische Centrale voor Herverzekering van Levensverzekeringsrisico's, die einde 1941 ook voor belanghebbenden in de West de gelegenheid tot aansluiting openstelde door tusschenkomst van de gelijknamige West-Indische Centrale. Een moeilijkheid was, dat alle Nederlandsche, en later ook de Nederlandsch-Indische, verzekeringsmaatschappijen zich in bezet gebied bevonden, op één na; deze eene was ,,de Nederlanden van 1845”, die haar zetel naar Curaçao had verplaatst. In Juli 1942 richtte deze maatschappij met medewerking van de Curaçaosche en Surinaamsche commissiën Regeling Rechtsverkeer in oorlogstijd op de Westindische Levensverzekeringscentrale. Bij deze nieuwe stichting konden zich aansluiten allen, die verzekerd waren bij ,,verweesde” maatschappijen, en zij, die bij de slechts kort bestaan hebbende Westindische Centrale voor Herverzekering van Levensverzekeringsrisico's onderdak gezocht hadden.

Deze maatregel was van vèr strekkende beteekenis. De eerste Nederlander, die na de bevrijding uit Curaçao naar Nederland trok, was de heer J. v. d. Velden, directeur van ,,de Nederlanden van $1845^{\prime \prime}$, die aanstonds de zaken ging afwikkelen in het belang der vele verzekerden.

Het gouvernement bewaart vrede. Langzaam drong in de kringen van het gouvernement een sociaal begrip door. Op het gebied der wetgeving nam men de werkliedenzorg ter hand, de stuwadoorsaangelegenheden en de ziekteregeling.

Een nieuwe Hygiënische dienst werd in het leven geroepen, behoorende tot den Openbaren gezondheidsdienst, die tot taak had toezicht uit te oefenen in winkels, op regenbakken, keuring van plantaardige levensmiddelen (de dierlijke vielen onder den Veterinairen dienst.)

In Nov. 1944 kwam een wet op de venerische ziekten tot stand. Spoedig ontstond er gebrek aan geneesmiddelen en aan medisch personeel. Surinaamsche en buitenlandsche artsen werden, met name bij de oliebedrijven, in dienst genomen. Surinaamsche vroedvrouwen voorzagen in het gebrek, ontstaan door het uitblijven van uit Nederland verwachte krachten. Geneesmiddelen betrok men uit Amerika, wat duurder was, maar ten minste in den nood 
voorzag. Het prijsverschil zal deze markt wel voor Nederland behouden doen blijven.

Uitbreiding onderging ook de Watervoorzieningsdienst. Op Aruba en Curaçao zocht men die uitbreiding in distillatieinrichtingen. Putten werden gebouwd ten dienste van de kostelooze watervoorziening. In de eerste oorlogsjaren bleek in de putten door den slechten regenval onvoldoende water te zijn. Op Aruba werd het water gerantsoeneerd tot enkele uren daags. Naast distillatie-inrichtingen voor zeewater werden nieuwe pompstations voor de winning van grondwater in bedrijf gesteld. Ook hier is de productie afhankelijk van den regenval. Een poging, in de eerste helft van 1942 op Aruba gedaan, om naar water te boren op een door een wichelroede aangewezen plaats, had geen gevolg. Bij de watervoorziening gingen de schepen voor.

De C. P. I. M. en Lago bleven voor zichzelf zorgen: fabriekswater, drink- en huishoudwater en water voor de eigen olieschepen. De Lago liet een tijdlang drinkwater uit de Vereenigde Staten komen. De waterleiding in Willemstad, in den oorlog tot ver daarbuiten uitgebreid, levert thans water tegen een vastrechttarief, afhankelijk van de huurwaarde.

De vrees voor uitputting van het grondwater ten nadeele van landbouw, veeteelt en natuurschoon deed het gouvernement in 1945 een Watercommissie in het leven roepen, die dit vraagstuk in studie heeft genomen. Watervoorziening door distilliatieinrichtingen komt op den duur vele malen duurder uit dan die met grondwater.

Nieuw departement. In 1943 werd een departement van Landbouw Veeteelt en Visscherij ingesteld onder leiding van den directeur der Landswatervoorziening. Men heeft vroeger den dienst van den landbouwkundige gekend, en later was de landbouw eerst nog (in 1940) bij Openbare werken ondergebracht, en Veeteelt en Visscherij bij den Veterinairen dienst. De ruime werkgelegenheid buiten den Landbouw had dezen, al steeds niet zeer gezocht, nog meer in discrediet gebracht. Nieuwe plannen naast de oude staan op stapel; er wordt gedacht aan mechanisatie. Er is groeiende belangstelling. Voor de veeteelt met name is in de oorlog veel gedaan. Er kwam een kweektuin op Cas coŕa, waar sierheesters, schaduw- en laanboomen, vruchtboomen en grassoorten worden geteeld. Er is een fokkerij met rasdieren. Aan het kweeken van groenten op groote schaal is men reeds begonnen.

Merkwaardige proeven, die men neemt, gelden watercultures, hydroponics of „,soilles culture”, aardelooze verbouwing, kwee- 
ken van planten in water. De C. P. I. M. is voorgegaan, en particulieren hebben getracht dit voorbeeld te volgen.

Voor het vee is krachtvoer ingevoerd moeten worden.

De bekostiging van dit alles! Tot dekking van de aanmerkelijk gestegen uitgaven werden verschillende belastingen en retributies verhoogd met opcenten. Deze opcenten stegen in sommige gevallen tot boven de 10: die op de Inkomstenbelasting liepen op van 25 in 1940/1 tot 100 in 1943; in 1944 waren zij progressief van 1 tot 75 ; winstbelasting 150 ; invoerrecht 10 , met verhooging van sommige rechten als op bier en wijn met $50 \%$, gedistilleerd met $2400 \%$, sigaren, sigaretten, tabak met $150 \%$; accijns op gedistilleerd 10 opcenten met verhooging van het recht zelf van 150 op 200 gulden per Hectoliter; loodsgelden 10 opcenten, met verhooging van het bedrag voor stoomschepen met $65 \%$.

Menschen achter prikkeldraad. In den nacht van 10 Mei 1940 werd gouverneur Wouters gewekt door een telegram van den minister van Koloniën, waarin het uitbreken van den oorlog werd gemeld. Een uur later trokken detachementen Militaire politie, mariniers en matrozen onder leiding van officieren door de stad om de Duitschers en staatsgevaarlijke „Nederlanders” in te rekenen. Een Nederlandsch oorlogsschip waakte buitengaats tegen ontsnapping van Duitsche schepen in de haven en baaien. 220 Duitsche schepelingen, 202 andere Duitschers, 28 ,Nederlanders” en 11 Nederlandsche onderdanen waren al opgeborgen, toen de bevolking op de been kwam. 8 menschen werden weer vrijgelaten. 71 huiszoekingen vonden plaats, 4 archieven waren in beslag genomen. De Duitschers gingen denzelfden dag naar Bonaire, de staatsgevaarlijk geachte „Nederlanders" kwamen in de gevangenis te Willemstad. Op Bonaire bleef een detachement Militaire politie ter bewaking achter. Hier zaten de geïnterneerden in scholen: 1 voor vrouwen en kinderen, 1 voor schepelingen en 1 voor mannen. Spoedig richtte Openbare werken een kamp in. De schepelingen gingen naar Jamaïca; 30 Duitsche vrouwen en kinderen en oude mannen mochten onder bepaalde voorwaarden naar Curaçao teruggaan.

De behandeling der geïnterneerden was niet weerwraak. In Jan. 1941 heb ik als journalist het kamp op Bonaire bezocht. Toen waren de Duitsche en statenlooze Joden al afgezonderd en op de plantage Guatemala ondergebracht, om hen voor beschimping te vrijwaren. Daar liepen ze met gebruinde ruggen te kuieren, lagen te lezen of kookten een extra eigen potje. In het groote kamp 
aan de zee hadden de Duitschers verlof om tweemaal daags te zwemmen. Zij leerden hier wat het beteekent in een beschaafd land politiek gevangene te zijn, waar de overheid, door christelijke beginselen geleid, aan de gerechtigheid weet te voldoen zonder de menschlievendheid te vergeten. De behandeling geschiedde overeenkomstig de bepalingen van het verdrag van Genève van 27 Juli 1929 betreffende de behandeling van krijgsgevangenen, zulks op verzoek der Duitsche regeering. De Zwitsersche zaakgelastigde te Caracas bezocht eenige malen het kamp en sprak met de menschen buiten tegenwoordigheid van derden.

Om het kamp, waarin ook de „Nederlanders”, door prikkeldraad gescheiden, waren, was een neutrale zône, en ieder, die zich daarin ophield, liep gevaar neergeschoten te worden. Toch zijn er in Sept. 1941 enkelen ontsnapt; zij werden echter weer gegrepen. In de keuken, tusschen het Duitsche en het Nederlandsche mannenkamp, was voor de gevangenen gelegenheid om een extra kopje koffie te zetten. Eens per week konden zij naar de stad gaan om inkoopen daartoe te doen. Elke morgen om 10 uur was er inspectie naar de bedden en de barakken. Ander werk geschiedde tegen betaling. De Joden op Guatemala werkten op eigen verzoek in de groenten. Van de 80 Duitschers verklaarden 10 desgevraagd te willen werken, maar dezen werden daarover door de anderen lastig gevallen.

Langs hierarchieken weg konden de geïnterneerden klachten indienen. De eerste instantie was de kampchef, door de gevangenen uit hun midden gekozen met goedkeuring van de militaire overheid. Ontduiking van den verplichten kampdienst, kwetsend spreken over Nederland werden gestraft, maar lijfstraffen werden niet toegepast. De geestelijke verzorging der geïnterneerden was in handen van de plaatselijke geestelijkheid. Bij den kerkgang, eenmaal des zondags, bleken velen des morgens katholiek en 's middags protestant te zijn. De gouvernementsgeneeskundige hield tweemaal in de week spreekuur, en daarbuiten kon men bij den kampchef naar hem vragen.

In den loop van 1941 ging men over tot gezinsinterneering. Op 1 Sept. van dat jaar werd den Joden en antinazi's veroorloofd naar Aruba en Bonaire te gaan onder zekere voorwaarden, waaronder een dagelijksche aanmeldingsplicht bij de politie en verbod van politieke bemoeienis. Eén moest wegens overtreding der voorschriften in de interneering terugkomen.

De Nederlandsche geïnterneerden zijn een tijdlang werkzaam geweest bij de wegenverbetering op Bonaire. 
Zes Italianen op Curaçao en 1 op Aruba zijn na het uitbreken van den oorlog met Italië geïnterneerd. $\mathrm{Zij}$ werden al spoedig gebracht onder de ,beperkt vrijgelatenen." Voor deze categorie in haar geheel werd in 1943 een verbod van het bezoeken van openbare vermakelijkheden uitgevaardigd.

Mag men eenerzijds aannemen, dat de geïnterneerde vijanden op Curaçao het veel beter hadden, dan de Nederlanders, die een deel van hun leven in vijandelijke concentratiekampen hebben moeten slijten, anderzijds bestaat wel de indruk, dat de Curaçaosche overheid strenger was in het interneeren dan die in Engeland en Amerika. In laatstgenoemd land werden statenloozen wel in het leger opgenomen en soms zelfs genaturaliseerd. Een merkwaardig geval, dat zich heeft voorgedaan, was het volgende, van twee broers, die voor het naziregiem uit Duitschland vluchten, kwam de een op Curaçao en de ander in Engeland terecht; de eerste werd hier als ,,beperkt vrijgelatene” behandeld, terwijl de andere in Engeland bij de geheimen dienst aangenomen werd.

Wat er met de kampbewoners zal gebeuren, is nog niet bekend. De Staten hebben bij voorbaat de begrootingspost voor onderhoud van het kamp afgestemd.

De olie. - Zonder Aruba en Curaçao had de luchtmacht niet kunnen vliegen - $\mathrm{Na}$ die aan de Perzische golf liggen de twee grootste olieraffinaderijen op Curaçao en Aruba. In de betrekkelijke rust van het Westelijk halfrond zoemden de motoren en stroomde de olie, de benzine, de 100 octaan olie voor de luchtmacht. Alleen wie de eilanden kent, kan zich een voorstelling maken van den enormen omvang dezer bedrijven. Men kan met een 35 K.M.-snelheid ongeveer een uur op de terreinen der C.P.I.M. rijden, zonder tweemaal denzelfden weg te nemen. In de olieproductie bereikt de oorlogsinspanning van Curaçao haar toppunt Bij de C. P. I. M. werken naast 500 krachten uit Europeesch Nederland een 7100 arbeiders, waarvan ongeveer de helft Nederlandsche onderdanen zijn of Nederlanders, waarvan 2200 van het eiland Curaçao en 50 van Aruba, 240 Bonairianen, 20 Statianen, 100 van St. Maarten en 15 van Saba; daarnaast nog een 650 uit Suriname.

Deze arbeiders werken in ploegen. Het begon te spannen, toen niet minder dan 250 arbeiders onder de wapenen werden geroepen.

Bij de Lago Oil \& Transport Company op Aruba werken „,slechts" 7000 menschen, van welke 6400 uit het gebiedsdeel Curaçao. De Lago geeft de voorkeur aan Arubanen boven 
Curaçaoenaars en daarna aan menschen uit ander Caraïbisch gebied.

Reeds in 1939 werkten beide raffinaderijen voor den oorlog. In 1940 werd de C. P. I. M. daarbij meer rechtstreeks betrokken. De Lago sinds Pearl Harbour. Er werd op beide eilanden voor tientallen millioenen bij gebouwd om aan de steeds toenemende vraag te kunnen voldoen. Om het Schottegat op Curaçao staan de installaties thans tot aan het Joodsche kerkhof, op het oude landgoed De Hoop. Het Schottegat heeft aan den rand een soort bassins gekregen, waar de afval in gaat. Had dit niet anders gekund? Het landschapsschoon heeft de olie nagenoeg geheel verwoest. Er staan thans meer dan 1000 tanks, en de productie liep in den oorlog zoo op, dat thans per dag 25 tot 30.000 ton geraffineerd wordt. Dat is een hoeveelheid,die 30 treinen, elk van 100 wagens, voor het vervoer zou eischen.

Op Aruba alleen werd voor een waarde van 15 tot 20 millioen dollars voor de inrichting aangevoerd. Voor een deel kwamen deze goederen op z'n Amerikaansch, per vliegtuig. Nacht en dag, ondanks de verduistering. Een katalysator-kraakinstallatie van 20 verdiepingen kwam in Dec. 1943 gereed.

Aruba en Curaçao hebben samen, na New York, de grootste havenbeweging ter wereld. De havenmeester, overste Gauw, werd in den loop van den oorlog opgevolgd door overste $\mathrm{H}$. W. Hemmes. In 1942 was de gemiddelde maandelijksche beweging 422 schepen, waarvan ongeveer 300 ,lakers”, ondiepe tankschepen. Ondanks de bescherming der motortorpedobooten en oorlogsschepen, zijn, gelijk gezegd, tankschepen getorpedeerd.

Ter opleiding van het personeel werden beroepsscholen opgericht; op Aruba had deze opleiding 50 tot 100 jongelui; die van de C. P. I. M. 150 leerlingen. Administratieve leergangen leidden eveneens nieuw personeel op.

De geweldige toeneming van het havenverkeer leidde tot den bouw van een nieuw dok door de C. P. I. M. ,naast het Wilhelmina- en het Julianadok, het Beatrixdok, dat in 1943 gereed kwam. Schepen en machines voor de schepen kunnen geheel hersteld worden op Curaçao. Daartoe komen schepen onder velerlei vreemde vlaggen.

Ten gerieve van het personeel der olieraffinaderijen zijn voorzieningen getroffen: electrische centrales, watervoorzieningssystemen, aanvoer van zoetwater met tankschepen, distilleering van zeewater, waterputten, sportterreinen, waterplantages. De 
C. P. I. M. opende een eigen openluchtbioscoop. De C. P. I. M. beslaat in het geheel 45 hectaren.

In December werd een aan de op Curaçao werkende verwante raffinaderij tijdelijk gesloten.

Uitbreiding der bevolking. Tusschen 31 Dec. 1939 en 31 Dec. 1944 steeg het bevolkinscijfer van het gebiedsdeel van 105.617 tot 127.866. Hieronder is de verbetering van een telfout van 6000 personen begrepen. Daartegenover staat, dat een 10 tot 12000 tijdelijk toegelaten personen, vreemde soldaten en ambachtslieden en vluchtelingen niet zijn ingeschreven. Over de eilanden verdeeld waren de cijfers, achtereenvolgens in 1939 en 1944: Aruba 30.416 en 39.318 Curaçao 65.231 en 78.587 Bonaire 5.563 en 5.798 St. Eustatius 1129 en 1092 St. Maarten 2039 en 1877 Saba 1194 en 1194.

Aruba is ongeveer zoo groot als Texel, dat een goede 8000 inwoners heeft; Curaçao en Bonaire zijn iets grooter.

De helpende hand. Er waren veel steunacties ten bate van het moederland. Reeds in de eerste oorlogsdagen begon men daarmee. De daarbij bereikte cijfers moet men zien in het licht van de bevolkingscijfers.

Het eerst werd opgericht de Stichting $S A N O C$, steun aan Nederlands oorlogsgetroffenen Curaçao, met de Sanoa op Aruba en de Sanom op St. Maarten. In den loop van de oorlogsjaren trad deze stichting minder op den voorgrond.

Het Roode Kruis stichtte in Mei 1940 dadelijk een informatiebureau. Het regelde de verzending van voedselpakketten over Lissabon enz.

Het Comité Nederland bestond uit werknemers bij de C. P. I. M., die een percentage van hun salaris afstonden. Tot het laatste toe ontving het belangrijke vrijwillige bijdragen. Maandelijks schonk het comité 300 pond aan het Welfare Committee for the Netherlands Fighting Forces in Engeland. Bovendien stelde het in 1944 twee ton beschikbaar voor het Nederlandsche Roode kruis ter onmiddellijke hulpverleening aan kinderen in Nederland. Kort na de bevrijding werd het ontbonden.

Dit comité gaf de stoot tot de oprichting van het Prins Bernhard Fonds op 10 Aug. 1940, het centraal bewapeningsfonds, waaraan Nederlanders en Nederlandsche onderdanen konden bijdragen. De heer J. M. de Booy, de tegenwoordige minister van Marine, toen een der directeuren van de Kon. Ned. Mij. tot exploitatie van petroleumbronnen in Ned. Indië, luit. admiraal J. Th. 
Fürstner en generaal-majoor jhr. W. C. M. de Jonge van Ellemeet, adjudant der Koningin, waren de oprichters. In het eerste jaar reeds werd meer dan 11 millioen door de Oost bijgedragen, Curaçao, Aruba, Suriname, Groot-Brittannië en Ierland, Argentinië, Australië, Belgisch Congo, Bolivia, Brazilië en tal van andere landen.

De Fellows of the Bellows was een origineel uitgedachte organisatie, die ook op de Curaçaosche eilanden instemming heeft gevonden, ter ondersteuning van de R. A. F. Voor elk neergeschoten vliegtuig werd een bijdrage gezonden.

Het Prinses Margrietfonds was een stichting ten bate van oorlogslachtoffers. De afdeeling Curaçao bracht enkele tienduizenden bijeen.

De stichting Katholiek Nederland beoogde hulp te verleenen bij het herstel van Katholieke cultureele instellingen in Nederland en Indië.

Het $A B C$-fonds, dat vooral op Aruba veel succes had, hield zich meer bepaald bezig met de zorg voor baby's.

Het Comité-Irene is eigenlijk een onderdeel van het Curaçaosche Roode kruis. Het vervaardigde kleeding, waarvoor het zelf de fondsen bijeenbracht.

De VOC of Vrouwenorganisatie Curaçao deed veel goed werk.

Het Curaçaosch Nationaal Steunfonds en het Aruba Hulpfonds werden geboren uit denzelfden drang, die het aanzijn gaf aan het Nationaal Steuncomité te Londen.

In Novenber 1942 werden op Aruba duizenden bijeengebracht voor hulp aan de Russen.

Ook voor andere dan met den oorlog in verband staande doeleinden werden gelden ingezameld. Bij de overstrooming van de Orinoco in Venezuela verleenden Aruba en Curaçao hulp in geld, en de K.L.M. zond een vliegtuig met geneesmiddelen.

Prof. dr. J. A. C. Fagginger Auer bezocht in 1943 Curaçao voor zijn plan om een Internationale universiteitsstichting in het leven te roepen, die een cultureele centrale voor geheel Europa in Nederland wilde vestigen. Particulieren, vereenigingen en ook de Staten gaven geld.

Een Joodsch Noodfonds bood hulp in bijzondere gevallen aan Joodsche personen; overigens droegen de Joden in ruime mate bij aan de andere fondsen.

Ter ondersteuning van verschillende fondsen werden bijzondere postzegels uitgegeven en met bijslag verkocht. Hier volgt voor postzegelliefhebbers een opgave van de in de oorlogsjaren verschenen postzegels: 
Frankeerzegels met beeltenis van de Koningin, teekening Konijnenburg, uitgegeven in 1941 en 1942.

Luchtpostzegels met een bijslag voor het Prins-Bernhardfonds, 11 Dec. 1941.

Luchtpostzegels, vliegtuigtype ter vervanging van het Hermestype, Sept. 1942.

Frankeerzegels, eilandentype met gezicht van Curaçao, Aruba, Bonaire, St. Maarten, St. Eustatius en Saba. Uitgegeven 1 Febr. 1943,

Frankeerzegels ter herdenking van den geboortedag van prinses Margriet, 8 Nov. 1943. Waarden $11 / 2,21 / 2,6$ en 10 cent.

Overgedrukte luchtpostzegels met een bijslag voor de Nederlandsche krijgsgevangenen, 40, 45, 50 en 60 cent. Uitgegeven 1 Dec. 1943,

Luchtpostzegels met een bijslag voor het Nederlandsche Roode Kruis, 16 Aug. 1944.

Toen de bevrijding daar was, wachtte men met ongeduld op de gelegenheid om pakketten naar Nederland te zenden. In Mei 1945 nog kon de Nigerstroom met ongeveer 4500 pakketten vertrekken. Op Scharloo was een extra-postkantoor ingericht; de menschen stonden er in de rij, en op straat liep ieder met een pakje. In October 1945 ging de Stuyveant met 12627 pakketten. De waarde werd op $21 / 2$ millioen geschat. Van Aruba werden iets eerder 1672 pakketten gezonden met twee vliegdekschepen, die regelrecht naar Pernis gingen.

Politiek leven. Het binnenlandsche politieke leven onderging in den eersten oorlogstijd een inzinking. Ontplooiing van politieke actie was eerst mogelijk geworden na de inwerkingtreding der Curaçaosche staatsregeling van 1936. Er waren toen drie partijen: de Roomsch-Katholieke partij, de Politieke unie en de partij der Curaçaosche Scheepvaartmaatschappij. Op Aruba hadden alleen de Roomsch-Katholieken een eigen partij. $\mathrm{Na}$ de eerste verkiezingen leken alle partijen verdwenen, maar de $R$. K. kwam tegen de verkiezingen van 1941 weer voor den dag. Ondanks het nieuwe kiesreglement kwam er geen levendige strijd bij de stembus. Velen meenden, dat om den oorlog de verkiezingen hadden moeten zijn uitgesteld, en onthielden zich, toen, dat niet geschiedde. Op Bonaire en de bovenwindsche eilanden werden bij candidaatstelling gekozen J.A. de Jongh en W. R. Plantz.

Op Aruba kwam J. H. E. Eman met een eigen lijst. De R. K. toonden weinig belangstelling, en zoo gebeurde het, dat in Nov. 
1941 op Aruba niet één candidaat der R. K. lijst werd gekozen, maar twee van de lijst-Emans, nl. J. H. E. Eman en F. J. Q. Kwartz. Van de beide andere lijsten werd ook niemand gekozen. Einde Jan. 1942 werd toen op Aruba de R. K. Unie Aruba gesticht, die in 1945 met een lijst voor den dag kwam.

Op Curaçao werden van de eenige lijst, die der R. K. partij, gekozen dr. M. F. da Costa Gomez, J. H. Sprockel, E. A. Römer, mr. A. W. J. M. Desertine, J.A. J. Ellis en J. M. F. Kroon.

De gouverneur benoemde een paar dagen na afloop der verkiezingen dokter J. R. Arends van Aruba, E. C. Martijn, C. N. Winkel, A. S. Señior en F. A. Vromans.

In den loop van dezen zittingstijd (1941-1945) werd in plaats van den ondervoorzitter C. N. Winkel, die ontslag nam, benoemd dokter W. P. Maal; ondervoorzitter werd de heer A. S. Señior. Deze laatste trad in Aug. 1945 af met den voorzitter Sproekel tengevolge van een geschil tusschen Staten en Gouverneur. In hun plaats werden benoemd Ch. B. Debrot en N. M. Chumaceiro. Voorzitter en ondervoorzitter werden mr. Desertine en de heer Vromans, beiden Europeesche Nederlanders, wat eenige kritiek uitlokte.

De Statenvergaderingen kenmerkten zich over het algemeen door zekere matheid. Ook zag men op de openbare tribune weinig belangstellenden. De redevoeringen waren meer practisch dan principieel; debatten kwamen bijna niet voor. Een oogenblik van historische beteekenis was het, toen, kort nadat de minister van Koloniën Welter in een conferentie met de Curaçaosche pers had gewaagd van de ,,veranderde structuur in het bestel des koninkrijks", gouverneur Wouters op 16 Juni 1941 plotseling de Staten in buitengewone vergadering bijeenriep en meedeelde door de Kroon te zijn gemachtigd om mee te deelen het voornemen van het opperbestuur inzake de aanpassing van de structuur van het Koninkrijk aan den eisch der tijden. De status van Oosten van West-Indië zou in overeenstemming gebracht worden met de beteekenis dezer gebiedsdeelen in de rijkseenheid.

Het inwendig staatkundig bestel der overzeesche gebiedsdeelen zou mee een punt van overweging op het programma uitmaken. Een rijksconferentie na de bevrijding zou de Kroon van raad dienen. In 1942 stelde gouverneur Kasteel een commissie in om deze zaken onder de oogen te zien.

In Maart 1942 reeds werden de leden voor de rijksconferentie aangewezen: mr. Da Costa Gomez, de Statenvoorzitter Sprockel en A. G. Statius Muller. Toen de oorlog lang duurde en Indië ver- 
loren ging, werd in Londen een Buitengewone Raad van advies ingesteld, waarin Curaçao vertegenwoordigd was door $\mathrm{mr}$. Da Costa Gomez. Van Febr. 1943 tot Sept. 1944 was hij in Londen, met een onderbreking in Sept. 1943, ten einde zijn Statenlidmaatschap niet te verliezen. De buitengewone Raad van Advies werd opgeheven in Sept. 1944.

Een merkwaardige gebeurtenis was, dat in Juli 1944 de Curaçaosche Roomsch-Katholieke partij bij den minister-president protesteerde, toen in het hervormde kabinet geen R. K. waren opgenomen.

Naar San Francisco. In Apr. 1945 was de voorzitter der Staten, de heer J. H. Sprockel, op de wereldconferentie der Vereenigde volken. Het geschil, dat tot zijn ontslag uit de Staten leidde, liep tusschen dit college en den gouverneur Kasteel; persoonlijke kwesties waren daaraan niet vreemd. 6 Apr. 1945 verlieten bij de behandeling van de veel te laat ingediende ontwerp-begrooting 4 leden (de hh. Maal, Plants, Eman en Kwartsz) de vergadering uit protest. Het ging over eenige kleine posten, te zamen 5000 gulden omvattende op een geheel van 26 millioen. Enkele maanden later werd bij de begrooting 1946 de geheele defensiepost afgestemd, niet om de cijfers maar meer uit protest tegen de houding, welke de gouverneur geacht werd aan te nemen. Toen was de voorzitter in San Francisco en de ondervoorzitter Señior op een monetaire zending naar Londen. Beiden waren integere mannen? Sprockel liet, als het pas gaf, in de vergadering het nationale geluid hooren en placht de rijkseenheid op den voorgrond te stellen.

Nieuw Leven. Tegen de verkiezingen 1945 begon het politieke leven weer wat op te bloeien. Tegenover de R.K. partij werd in 1945 een Democratische partij opgericht. Er was ook nog het weekblad Curaçao, overgebleven uit den tijd van de Politieke Unie van 1937. Het verklaarde buiten de Democratische partij te staan, ofschoon zijn redacteur, dr. De Regt een der candidaten van die partij was. De Democraat werd het orgaan der nieuwe partij. Eerst na geruimen tijd kwam het blad met de beginselverklaring en het program zijner partij, die onder leiding van den voorzitter, den heer E. Jonckheer stond. De orthodoxe protestanten, Hervormden en Gereformeerden, richtten in Juli 1945 onverwacht de Curaçaosche Protestantsche partij op, die een blad Recht en Vrijheid deed verschijnen. Voorzitter dezer partij is dr. W. J. Goslinga.

Zal er na de verkiezingen politieke belangstelling blijven? 
In de Politieraden. In de Raden van politie uit zich het politieke leven op de eilanden buiten Curaçao. Met de politie hebben deze raden niets te maken. Veel leven zit er niet in deze kleine colleges, samengesteld uit den gezaghebber en twee gekozen landraden. Dr. Da Costa Gomez heeft een paar jaar geleden in een rede verdedigd, dat deze Raden van politie staatsrechtelijk in de lucht hangen. Plannen tot decentralisatie van het bestuur deden den gouverneur de verkiezing van nieuwe landraden in 1943 uitstellen. Echter moest op Aruba een verkiezing plaats hebben wegens aftreden van dr. A. F. Dussenbroek, in wiens plaats A. Wever werd gekozen. De decentralisatie is nog niet werkelijkheid geworden. Leven is er nooit in deze raden geweest; door het verbeterde reisverkeer traden $\mathrm{zij}$ in hun representatieven vorm wat meer naar voren.

„Beloften maecken 't volck tot alle dinghen graag” (Vondel). Het streven naar grooter onafhankelijkheid van het gebiedsdeel ten opzichte van het moederland ging gepaard met een streven naar meer onafhankelijkheid der eilanden ten opzichte van elkaar. Dit was voorzien bij de totstandkoming van de staatsregeling van 1936 (zie artt. 117, 118). Reeds kort na zijn optreden deed gouverneur Kasteel een belangrijke stap in die richting. Hij benoemde een commissie - naar haar voorzitter commissie-Oppenheim geheeten - ter bestudeering van staatkundige aangelegenheden. In December 1942 werd zij geïnstalleerd. Leden waren prof. mr. A. S. Oppenheim, dr. W. Ch. de la Try Ellis, mr. dr. M. F. da Costa Gomez, dr. W. Goslinga, mr. C. F. Gronemeijer, mr. H. A. J. Gijsen en G. J. Ferguson, tevens secretaris. In April 1944 verscheen het rapport dezer commissie, gegoten in den vorm van een Ontwerp-Landsverordening. De gedachte is, dat alle eilanden krijgen een eilandraad, een college van gezaghebber en landraden, en een gezaghebber. Het eigenaardige is, dat in dit rapport de eilanden in alphabetische volgorde worden genoemd en niet naar hun belangrijkheid (C.,A.,B.) als vroeger. De leden van den eilandraad worden gekozen volgens een belasting-bekwaamheids-kiesrecht, waarbij op de bovenwindsche eilanden, als van ouds, is rekening gehouden met eigendom van onroerend goed. Het actieve vrouwenkiesrecht wordt voorgesteld, terwijl tot nu toe in Curaçao alleen een passief vrouwenkiesrecht voor de Staten bestaat, dat echter nog nooit, als in Suriname, in praktijk gekomen is. De leden zitten 4 jaar. De vergaderingen, ten minste eens in de maand, zijn openbaar. De gezaghebber is voorzitter, en heeft een raadgevende stem. Uit en door den eilandraad 
worden de landraden gekozen, ten minste 2 en ten hoogste 4 . Het college van gezaghebber en landraden is het dagelijksch bestuur van het eiland. De Staten van Curaçao worden meer een overkappend college, want ook op het eiland van dien naam komt een eilandraad en dus ook een gezaghebber. Een eigen begrooting wordt jaarlijks in den eilandraad vastgesteld.

Wordt dit alles wet, dan komt er een einde aan den ietwat patriarchalen toestand, die het zwaartepunt van het bestuur feitelijk in één hand legde. De gouverneur brengt de decentralisatie als een geliefkoosd onderwerp telkens ter sprake, maar in 1945 was het desbetreffend ontwerp nog steeds niet ingediend. Het geheel vertoont veel overeenkomst met de gemeentebesturen in het Rijk in Europa.

De gouverneur heeft over het voorstel het oordeel gevraagd van de belangrijkste ambtenaren. In sommige kringen is twijfel geopperd aan de beschikbaarheid van bekwame personen op alle eilanden, om in de colleges zitting te nemen. Op één uitzondering na verklaarden mij de landraden op de bovenwindsche eilanden, dat daar de geschikte personen in voldoende aantal zouden ontbreken, nl. onder hen, die voor openbare ambten zich beschikbaar willen stellen. Min of meer geldt dit ook voor de benedenwindsche eilanden, en men loopt ook de kans, dat er zullen zijn, die niet zullen willen, omdat zij den Eilandraad als van lagere orde dan de Staten zullen zien. Het nog niet volgroeide politieke inzicht van Curaçao doet zich hier gelden

Staats- of gebiedsdeel? Deze vraag deed eenigen tijd veel stof opwaaien. De gouverneur Kasteel en het statenlid mr. Da Costa Gomez voelden voor staatsdeel, wat ook juister is, omdat Curaçao enz. niet deelen van een gebied maar van een staat zijn. Enkelen bevelen ,rijksdeel” aan, maar de Grondwet noemt ,rijk" alleen het rijk in Europa. De levendige gedachtenwisseling over dit onderwerp ontaardde in allerlei persoonlijkheden en venijnigheden. De gouverneur zag in zijn voorkeur voor staatsdeel zelfs reden om de belastingpapieren ermee over te drukken. Ten slotte keerden allen behalve de gouverneur terug tot ,gebiedsdeel”

Van de wieg tot het graf. Curaçao is Suriname en Ned.-Indië ver vooruit op het gebied van de sociale wetgeving, maar een zekerheid ,"van de wieg tot het graf”, zooals sir William Beveridge het noemt, bestaat ook hier nog niet.

Ongevallen- en ziekteverzekering was er al in 1938 en 1940 gekomen. In den oorlog kon men allereerst in de kostwinnersver- 
goedingen een vorm van sociale zorg zien. Toen kwam de Algemeene Oorlogs- Ongevallenregeling voor oorlogsinvaliden. Het Roode Kruis bood hulp, toen verschillende koopvaardijschepen werden getorpedeerd. In den loop van $1942 \mathrm{kwam}$ een regeling tot stand voor de verzorging van oorlogsslachtoffers, naar het voorbeeld van de Oost-Indische regeling. De Lago bleef niet achter, toen slachtoffers vielen bij de beschieting van Aruba.

Men bleef ook voortwerken aan de uitvoering van het vóór den oorlog ontworpen program. Er kwam een Regeling Arbeidscontract, een Verlofregeling voor winkelpersoneel, een verbod van kinderarbeid, een regeling van de werktijden van kantoorpersoneel.

Voorts is voorbereid een Stuwadoorsverordening, waartoe de stoot werd gegeven door een staking onder de bootwerkers in den zomer van 1945. Er wordt gewerkt aan een Veiligheidswet, en men wil een arbeidsbeurs scheppen in een verordening op de registratie van arbeidskrachten.

Bij de C.P.I.M. kwam het tot de oprichting van een afdeeling AS, arbeids- en sociale zaken, kort na een bezoek in Nov. 1942 van den directeur der ,Koninklijke” J. M. de Booy, onder leiding van den secretaris der directie, tevens lid der Staten van Curaçao, F. A. Vromans. Een adviescommissie van personeel zorgt voor het verband tussen directie en werknemers.

In Oct. 1941 werd te Willemstad het Wit-Gele kruis opgericht ter bevordering van de volkshygiëne in den vorm van zorg voor ouden van dagen, gebrekkige kinderen, zuigelingen, van ziekenverpleging aan huis. De Loterijbond Fortuna en het gouvernement geven geldelijke hulp. Leergangen werden gegeven in hygiëne, infectieziekten, moederschapszorg; een vlugschrift Noten bij de moederschapszorg werd uitgegeven, als ook Een idee van enkele infectieziekten. Het Wit-Gele Kruis was een onregelmatig verschijnend ,periodiekje”. In Juli 1943 werd geopend een Tehuis voor ouden van dagen „Birgen di Rosario”. Tevoren was deze laatste zorg in handen van de Protestansche vereeniging voor Liefdadigheid, die al van 1936 af het fraaie Wilhelmina tehuis heeft. Op St. Eustatius werd in 1945 een tehuis Bethanië ingericht.

Wijkverpleging was er vóór den oorlog niet op Curaçao. Mede door een toenemend tekort aan krachten moest de opneming in ziekenhuizen beperkt worden. Het Wit-Gele kruis richtte in Juli 1943 onder den naam „Stichting Prinses Margriet” - de eerste inrichting, die dien naam mocht voeren - een wijkverpleging op onder een gediplomeerde hoofdzuster, die de menschen zonder onderscheid van geloof, stand en ras helpt. De inrichting voor 
gebrekkige kinderen, ,,O.L.V. van altijddurenden bijstand", zorgt voor gebrekkige kinderen. Een leergang van dr. H. G. S. van Raalte wil door opleiding van verpleegzusters het toenemend tekort aan verpleegsters verhelpen. Steeds meer landskinderen komen in het verpleegstersvak.

Echtscheiding en verstekvonnis. In Febr. 1944 kreeg de Curaçaosche rechter de bevoegdheid kennis te nemen van vorderingen tot echtscheiding, wanneer de eischende partij hoofd- noch werkelijk verblijf in Curaçao, Suriname of vijandelijk gebied heeft en de andere partij niet in vijandelijk gebied werkelijk verblijf houdt. Het werd een pijnlijke toestand, toen hier echtscheiding gingen vragen enkele personen, wier echtgenooten in Europeesch Nederland vertoefden, en bij verstek ook kregen. Begin Aug. 1945 maakte de gouverneur daarop een ontwerp-landsverordening aanhangig, die ook tot stand kwam, waarbij verstekvonnissen moeilijk, zoo niet onmogelijk gemaakt werd.

Zeelieden aan den wal. Curaçao werd een der grootste afscheephavens voor olie; schepen van tientallen naties werden de St. Annabaai binnengeloodst; er moest voor den zeeman iets worden gedaan. Het Apostolaat der zee, het Leger des Heils en Onze Vloot werkten samen. Aan het R.K. Zeemanshuis, in de Klipstraat gelegen, kon reeds op den Tweeden Kerstdag, dank zij een comité onder leiding van de dochter van den gouverneur, mej. E. W. J. Wouters, een nieuwe vleugel worden bijgebouwd, waarin 30 bedden voor nachtverblijf werden beschikbaar gesteld. Het Leger des Heils heeft een dergelijke inrichting aan de Hoogstraat, terwijl Onze Vloot op Suikertuintje een ontspanningsoord opende. De C.P.I.M. had een eigen zeemanshuis in Emmastad. Ook dient genoemd, dat het Comité Nederland en de Centrale van koopvaardijofficieren voor den zeeman werkzaam was. In de gastenboeken der zeemanshuizen staan de namen van prinses Juliana en prins Bernhard, ook die van de ministers, die Curaçao bezochten. Minister Kerstens vulde de kolom ,,welk schip” in met ,het schip van Staat".

De gaande en komende man. De oorlog heeft personen naar Curaçao gebracht, die anders wellicht nooit gekomen zouden zijn.

Gouverneur Wouters, die in 1936 gekomen was, werd in 1942 opgevolgd door dr. P. A. Kasteel. Eerstgenoemde zij hier in de eerste plaats herdacht als de man van de sociale wetgeving; hij haalde den ir. Verwey hier. Verder verbeterde hij de drinkwater- 
voorziening; op Aruba werd o.a. een waterinstallatie bijgebouwd. Persoonlijk had hij belangstelling voor de opsporing van water met de wichelroede. In de derde plaats wijdde deze gouverneur zijn aandacht aan de landsverdediging. Bij zijn sociale voorzieningen behoort genoemd te worden de woningbouw. Verder komen voor gouverneur Wouters' rekening de verbetering der vliegvelden, de stichting van het Stuyvesant-college, de verbetering van den rechtstoestand der ambtenaren, de uitbreiding van het krankzinnigengesticht, de herinrichting van den Openbaren gezondheidsdienst (schoolvoeding, schoolartsen), de vereenvoudiging van het kiesreglement en de uitbreiding van het kiezerscorps. De Administratie van Financiën kreeg in zijn tijd een nieuw kantoorgebouw, waarvandaan zij in 1944 verhuisde naar Pietermaai; Willemstad kreeg een nieuwe Emmabrug; het wegennet op de eilanden werd verbeterd en uitgebreid. Den landbouw moedigde gouverneur Wouters aan: het Helfrichdorp werd gebouwd, een modelboerderij ingericht; de bovenwindsche eilanden werden op dit gebied niet vergeten. Op Aruba werd het gouvernementshuis met de kantoren uitgebreid, er kwam een abbattoir en een markthal; deze laatste ook op Curaçao. Gouverneur Wouters voerde het registratuurstelsel der Vereeniging van Nederlandsche gemeenten in de administratie in en reorganiseerde de diensten van het Bevolkingsregister en van den Burgerlijken stand; het Kadaster werd verbeterd.

$\mathrm{Bij}$ dit alles - en er is meer te noemen (de havenverbetering op Aruba, de oprichting van het Bureau Sociale en Economische zaken, het comité Suriname-Curaçao, gevolgd door het comité Curaçao-Suriname ginds) - bedenke men, dat dit geschiedde in 6 jaren, waarvan 2 in den oorlogstijd vielen.

Het is niet dikwijls voorgekomen, dat in Curaçao de aftredende gouverneur persoonlijk de bestuursmacht overdroeg aan zijn opvolger. Het was onder gouverneur De Jong van Beek en Donk gebeurd, en geschiedde nu weer, toen gouverneur Kasteel het bewind aanvaardde op 15 Juli 1942.

Gouverneur Wouters verliet Curaçao, waar het Kerkplein op Pietermaai als Gouverneur-Woutersplein zijn naam in herinnering houdt. Hij werd lid van den Caraïbischen Onderzoekingsraad, die eerst te Washington, later in New York gevestigd was.

Gouverneur Kasteel kwam met nieuwe denkbeelden. Een zijner eerste maatregelen was de vrouwendienstplicht, in Nov. 1942 ingevoerd, maar niet tot uitvoering gekomen. Door verschillende commissies liet de gouverneur zich voorlichten: de Vervoercom- 
missie (Aug. 1942), de Havencommissie (Oct. 1942), een commissie (Jan. 1943) voor financieele en scheepvaartbelangen, die een afvaardiging naar de Vereenigde Staten van Amerika zond, zooals later ook een voor het monetaire vraagstuk, een commissie tot regeling van den Burger- en Vrouwenarbeidsplicht (Mei 1943), een voor agrarische vraagstukken (Dec. 1943), voor eigendomsuitwijzing (Jan. 1944), voor radio-aangelegenheden (Apr. 1944), een adviescommissie voor handelsaangelegenheden en een voor de notarieele tarieven.

De salarissen werden met $20 \%$ verhoogd, hetgeen noodig was door den duurderen levensstandaard en de hoogere salarissen, die de groote maatschappijen betaalden.

In het ambtenarencorps kwamen in den oorlogstijd veel veranderingen. Onder gouverneur Wouters verliet de doctorandus L. F. Jansen in het najaar van 1941 de afdeeling Sociale en Economische zaken, waar hij werd opgevolgd door drs. J. H. van Boven. In Juni werd mr. H. I. Franke als administrateur van Financiën opgevolgd door mr. H. J. M. Hoogeveen, die tevoren op Sumatra was werkzaam geweest. De havenmeester W. Gauw werd in Juli 1943 vervangen door den overste $\mathrm{H}$. W. Hemmes. De directeur van den gezondheidsdienst dr. W. Bonne maakte in Sept. 1943 plaats voor dr. J. de J. Arends, een Arubaan. De procureurgeneraal $\mathrm{mr}$. T. van der Laan werd opgevolgd door $\mathrm{mr}$. L. C. Kwartz, eveneens van Aruba. De garnizoenscommandant kolonel L. Langeveld werd in Febr. 1944 vervangen door majoor E. L. Venema, die al hoofd der politie was en bleef.

In Juni 1944 vertrok plotseling het hoofd van den gouvernementsperdienst mr. E. M. Elias, die opgevolgd werd door zijn assistent E. A. Winters.

De bovengenoemde directeur van Sociale en Economische zaken Van Boven verliet den dienst en met de waarneming zijner betrekking werd mr. Da Costa Gomez belast. De merkwaardigheid heeft zich toen voorgedaan, dat dit Statenlid tevens ter vergadering van de Staten verscheen als bestuurgemachtigde. In 1945 (1 April) had een splitsing van dezen dienst plaats. Het geheel kwam onder de Administratie van Financiën, en mr. L. A. Weeber kreeg de sociale zaken, mr. Ph. J. Evertsz de economische en crisiszaken te beheeren.

Mr. Gronemeijer, de gouvernementssecretaris, werd in Nov. 1944 opgevolgd door F. J. J. Corver. De gezaghebber der bovenwindsche eilanden J. D. Meiners werd vervangen door P. van Leeuwen, gezaghebber van Bonaire, in welke hoedanigheid de 
gezaghebber van Saba H. C. M. Krugers hem opvolgde. De heer Meiners ging over naar den Watervoorzieningsdienst.

Mr. L. C. Kwartsz, in Maart 1944 benoemd tot procureurgeneraal, werd een jaar later gezaghebber van Aruba in plaats van $I$. Wagemaker, die na een langen staat van dienst in deze functie met pensioen ging.

In de plaats van de heeren J. Cohen Henriquez en A. G. Statius Muller werden in den Raad van Bestuur benoemd dr. W. Ch. de la Try Ellis en prof. mr. A. S. Oppenheim; eerstgenoemde werd ondervoorzitter. prof. Oppenheim vertrok spoedig. Andere leden van dezen raad waren C. N. Winkel, J. A. Correa en dr. E. M. Arends, welke laatste als eerste Arubaan zitting nam.

M.P. Gorsira werd in Febr. 1945 inspecteur van politie.

Uit dit overzicht van benoemingen in de laatste jaren blijkt het streven om het landskind meer naar voren te schuiven.

Bezoekers. Tot het incident van Pearl Harbour kwamen er toeristenbooten. Kort daarop hield dit op. Dit beteekende geldelijke schade, maar de aanwezigheid van Amerikaansche troepen, die na de eerste maanden nog altijd een $\$ 300.000$ per maand uitgaven, ving deze schade op.

Van de oorlogsgasten moet genoemd James Roosevelt, zoon van den president. Dat was in 1941, in Februari. Op zijn terugreis van Casablanca was de president zelf kort op Hato, maar niemand heeft dat toen geweten. In hetzelfde jaar (1941) kwam de minister van Koloniën Welter, als eerste van die functionarissen, die hier in zijn ambtstijd voet aan wal zette. Later kwam hij weer, op terugreis van Zuid-Amerika. Ook de minister van Handel, Nijverheid, Scheepsvaart, Landbouw en Visscherij, P. A. Kerstens was hier en op Aruba in Juli 1942; ook hij kwam terug, in Dec. 1943. De derde minister J. Th. Fürstner, van Marine, was hier in Sept. 1942, en dr. H. J. van Mook met Raden Mas Loekman Djajadiningrat en generaal-majoor L. H. van Oyen kwamen in December van dat jaar. Voorts moeten genoemd als bezoekers: oud-minister mr. M. P. L. Steenberghe, dr. N. A. C. Slotemaker de Bruïne, gedurende langen tijd in Indië werkzaam bij de zending en in de journalistiek, dr. A. Loudon, de ambassadeur te Washington, met dr. Van Houten (Apr. 1943), jhr. mr. L. F. K. van Vredenburch, van dezelfde ambassade, enkele malen, ook ir. L. A. H. Peters, landbouwattaché te Washington, René Pratt, schaakkampioen (Apr. 1943), dr. A. Methöfer, gezant in Caracas (Mei 1943) en de consul Van Egmondt. Van de militaire bezoekers moeten nog genoemd kolonel Weyerman, Overste Nuboer, schout 
bij nacht Termijtelen. Admiraal Robert van Martinique bracht in den critieken tijd van Pétain een bezoek aan Fransch St. Maarten en bezocht daarbij ook Philipsburg. De hoogleeraren prof. dr. I. Pines te Caracas en prof. Snapper bezochten het Sint- Elisabethsgasthuis en het sanatorium van het Groene kruis.

Gedurende ongeveer 3 jaar woonde op Curaçao dr. J. C. de Groot, vroeger leeraar aan het R. K. gymnasium te Utrecht, in Mei 1941 via Rio de Janeiro op Curaçao beland. Zijn vrouw, een Poolsch-Fransche, mevrouw A. de Groot-Sobocka, deed veel schilderwerk op Curaçao.

Prof. dr. J. van der Veldt O.F. M., hoogleeraar aan de Propaganda te Rome, is uitgeweken naar New York, werd hoogleeraar te Washington, bezocht Curaçao tweemaal, en hield hier lezingen. Dat deed ook prof. dr. J. A. de Haas, geboren Nederlander, hoogleeraar te Cambridge Mass.

Voor cultuuruitwisseling was hier de directeur van de afd. Cultuur van het Venezolaansche departement van onderwijs J. N. Sardi.

In Nov. 1943 kwam hier onverwacht dr. A. E. von Saher, een Amsterdamsch advocaat, in verband met een proces in zake prijsrecht. Hij maakte hier vele vrienden.

De Chineesche vliegster Ya Chin Lee werd in Juli 1944 op Curaçao gehuldigd. Een dochter van generaal Uros Mikic, den veroveraar van Beograd in Nov. 1918, thans gehuwd met ir. F. C. Meuser van de K.L.M., woonde in 1941 op Curaçao en deed hier veel voor de vriendschap tusschen Nederland en Yoego-Slavië.

Als diplomaten noem ik nog: den Zwitserschen gezant te Caracas Gonzebach, den Zweedschen gezant aldaar en de Zweedsche gezant in Bogota Vendel, die door zijn verblijf in Nederland de taal van dat land spreekt, de zaakgelastigde van de Heilige Stoel mgr. Paolo Bertoli op Haïti en San Domingo.

De echtgenoote van wijlen president Roosevelt was in het voorjaar van 194421 uur op Curaçao en zag kans heel Curaçao af te zien, en ook nog een persconferentie te houden.

De president van Haïti E. Lescot bracht in Juli 1944 een officieel bezoek aan Curaçao.

Hier waren ook de letterkundigen Herman de Man en J. Villiers Farrow, schrijver van Damiaan de Melaatsche. Ph. Hanson Hiss bezocht ons land in opdracht van de Ned. regeering. Hij maakte hier en in Suriname foto's, wat later in een fraai uitgevoerd boek Netherlands America verscheen. Joh. Fernhout, een kleinkind van Toorop, was hier om films te nemen. 
Pater Stephanus Kuypers CssR., Apostolisch provicarius van Suriname, en de beroemde Indianenkenner pater W. Ahlbrinck CssR. bezochten Curaçao. Eind 1943 kwam hier ds. Raillard, pater Geldens, aalmoezenier in New York, rector Mommersteeg van het het Center of information Pro Deo in New York, oud- rabbijn Baruch Ducque.

P. J. van den Berge, voorzitter van de Centrale van transportarbeiders, onderzocht in Januari 1945 ter plaatse, of hier een afdeeling van zijn vakvereeniging kon opgericht worden. Uit een rapport van zijn hand bleek, dat hij wel zeer oppervlakkig over de sociale toestanden in Curaçao was ingelicht.

Van de petroleum waren hier J. M. de Booy, dr. J.C. Panthaleon baron van Eck, dr. A. M. Meerloo.

A. Plesman kwam kort na de bevrijding, Juli 1945. Hij verwachtte medio 1947 een wekelijkschen vliegdienst AmsterdamSuriname-Curaçao te kunnen openen, reisduur 30 uren, kosten \pm 1000 gulden.

De tweede Oranjeprins op Curaçao. Het was de Amigoe di Curaçao, die, toen prins Bernhard zijn eerste bezoek aan zijn gezin in Ottawa bracht, de gedachte uitsprak, dat de prins ook wel Suriname en Curaçao zou bezoeken. In 1835 was op Curaçao en St. Maarten Prins Hendrik, de derde zoon van Koning Willem II, geweest. De gouverneur zond prins Bernhard een uitnoodiging, enhet heeft lang geduurd, maar - de prins is gekomen. Dat was met het door hemzelf bestuurde vliegtuig Lockheed XII, op 22 Oct. 1942. De gouverneur was er niet - het vliegtuig kwam vóór het verwacht werd. Toen dr. Kasteel er was, stelde de prins voor naar het vliegtuig terug te gaan en het uitstappen nog eens over te doen. Langs overvolle wegen en straten ging het over Santa Maria en Suikertuintje op de Grezelligheid en het fort aan. 's Avonds ontving prins Bernhard de Staten; de voorzitter J. H. Sprockel hield een toespraak, die de prins beantwoordde. „Niet zonder groote ontroering heb ik na ruim 2 jaar op vreemde bodem vertoefd te hebben, weer Nederlandschen grond betreden", zei de prins voor de Curom. Sanoc bood een som gelds aan, een aubade werd gegeven; Waterfort, R.K. zeemanshuis en het zeemanshuis van het Leger des Heils werden bezocht; de gouverneur gaf een noenmaal en de prins hield een ontvangst, bezocht de C.P.I.M., voer over het Schottegat met het gouverneursjacht Beatrix en schouwde de troepen. Op Aruba werden rondritten gemaakt, de Lago, de kustbatterij en de Bernhardschool bezocht. 
Van Donderdagmiddag tot Zondagmorgen vertoefde de prins hier, toen vloog hij door naar Suriname.

De prinses, die in Nov. 1943 bij gelegenheid van haar bezoek aan Suriname Haar voorgenomen bezoek aan Curaçao moest uitstellen wegens een hier heerschende epidemie, vloog wel over de drie bovenwindsche eilanden, zond speciale groeten daarheen uit en werd naar boven toegezongen door de schooljeugd in oranjedos.

De Prinses ${ }_{v}$ Op dien gedenkwaardigen Zaterdagmiddag van 26 Febr. 1944 streek te één minuut voor half vier de Meeuw met de koninklijken standaard in top neer. Men was stil van bewogenheid. Geen mensch kon juichen; geen stem deed zich hooren. Luchtig stapte prinses Juliana uit het vliegtuig. De overheidspersonen begroetten haar. Liesje Sprockel mocht bloemen geven. Een oudstudiegenoote uit Leiden begroette de prinses. De Postharmonie deed het Wilhelmus hooren. De prinses schouwde de Nederlandsche en de Portoricijnsche troepen. En toen eerst, na minuten van ontroerd zwijgen barstte de jubel los der duizenden, die naar Hato waren gekomen. Grootscher oogenblik kent de geschiedenis van Curaçao niet. In de hal stonden alle moeders, die haar kindje Margriet hadden genoemd.

Een zegetocht was de gang langs de nieuwen weg tot voorbij Santa Maria, waar pastoor, onderwijzeressen en schoolkinderen hulde brachten. Langs de Isla stond het zwart. Op Groot-Kwartier beierden de klokken. Bij Monte Christo hadden zusters en verpleegden zich opgesteld, bij Suikertuintje de zeelieden, bij Zeelandia de ouden van dagen. Bij het binnenrijden van de hoofdstad juichten de klokken der stadskerken de vreugde uit. Woutersplein en Wilhelminaplein waren vol. Van bij de Gezelligheid ging de prinses te voet naar het gouvernementshuis, waarop haar standaard geheschen werd. Tweemaal kwam de prinses voor het venster. De voorzitter der Staten sprak namens de bevolking. Weinigen meer dan de leden van het college woonde deze tegelijk plechtige en ontroerende samenkomst bij. Daar sprak de prinses: „Hoe zouden mijn man en ik vergeten wat Curaçao voor ons en onze kinderen deed!” en voor den Julianazender: „Ik herken hier alles, wat ik over Curaçao van mijn man heb gehoord; maja, masja danki!"

In de fortkerk woonde de prinses den dienst, door ds. Eldermans geleid, bij. Vijfduizend leden van Curaçaosche organisaties, waaronder een folkloristische wiri-wiri-groep, trokken in het Rifstadion aan haar voorbij. Zij bracht een bezoek aan den Noord-Ameri- 
kaanschen opperbevelhebber T. E. Chandler, die een jaar later in den strijd tegen den Japanner het leven liet. Op het binnenhof van fort Amsterdam was een gala-ontvangst zonder uiterlijk vertoon van avondkleedij, opdat iedereen eraan zou kunnen deelnemen. Op dezelfde plaats hadden al eerder 10.000 kinderen een zanghulde gebracht. Vóór het Stuyvesantcollege onthulde de prinses het standbeeld van Peter Stuyvesant. Te Barber nam zij een folkloristische, maar nog echt levende , ,maishulde” in ontvangst.

Op 1 Maart betuigde Aruba zijn trouw aan Oranje. Een stoet van 7 vliegtuigen had de prinses daarheen gebracht. Het was daar een herhaling van wat Curaçao geweest was: een zanghulde van 1400 kinderen van 40 nationaliteiten, ziekenbezoek, officieele begroetingen.

Teruggekeerd op Curaçao maakte de prinses een rondrit, waarbij de C.P.I.M. werd bezocht. De staf van de Nederlandsche troepen kreeg een bijzonder bezoek in het Waterfort.

Ook Bonaire werd bezocht.

Weer een autotocht over Curaçao. Op Scherpenheuvel herinnerde frater Radulphus eraan, dat de stichter van de „Fraters van Tilburg" een vriend van koning Willem II was geweest.

De plaatselijke bladen verschenen in feestelijke opmaak.

Een grootsche ontvangst werd prinses Juliana bereid te Caracas, de hoofdstad van Venezuela. Zij kreeg daar uit handen van generaal I. Medina Angarita de Orde van den Bevrijder in het grootkruis.

Op de terugreis bezocht de prinses St. Maarten. De gezaghebbers der drie eilanden ontvingen Haar op het juist gereed gekomen vliegveld, dat Prinses-Juliana-vliegveld werd gedoopt. Een dag vol ontroering, de laatste van een zeker ook voor Haar onvergetelijk bezoek.

De hoofdstad der Dominicaansche republiek bereidde Haar een grootsch onthaal.

De heer E. A. Winters gaf na het vertrek een door dit bezoek geïnspireerd sprookje uit bij de Augustinusboekhandel „De Prinses en de drie verborgen schatten".

Protestantsch leven. In de oorlogsjaren bleek in de protestantsche groepen een geestelijke opleving. Er werden na den Duitschen inval in Nederland kerkdiensten gehouden, die herhaald werden telkens, als de ontwikkeling der gebeurtenissen daartoe aanleiding gaf. Bij het schoon schip maken ten behoeve van de militairen in de bergruimten onder de fortkerk kon een officier, daarbij 
tegenwoordig, nog iets redden van de voor de geschiedenis zoo kostbare papieren, daar geborgen.

In deze kerk moesten de avonddiensten worden gestaakt, omdat na zonsondergang niemand meer werd toegelaten in het fort. In Mei 1942 kwam hier een nieuwe predikant in den persoon van ds. J. Mietes. Hij nam ook de koopvaardijvloot voor zijn rekening, en ds. Eldermans de zorg voor de geestelijke belangen der militairen.

Als afdeeling van de Vereenigde Protestantsche gemeente werd in Nov. 1943 een Evangelische Broedergemeente opgericht, die een voorganger kreeg in den heer R. Doth.

In 1944 gingen alle kerken meewerken aan de godsdienstige uitzendingen van de Curom.

In April 1945 werd het 310 jarig bestaan van de „Hervormde” gemeente gevierd en het 120 jarig bestaan van de V.P.G.

Op Curaçao verrees een Methodisten gemeente met ongeveer 1400 zielen.

Ds. Steenstra kon in het begin van den oorlog een nieuw kerkgebouw op Rooi Canarie openen. Voor de Surinaamsche leden werd een eigen wijkgebouw geopend. Voor Noord-Amerikanen en Noren werden afzonderlijke diensten gehouden. Ds. Steenstra was van Juni 1943 tot Maart 1944 voor studiedoeleinden in de Vereenigde Staten. Na zijn terugkeer begon Ons Kerkblad weer te verschijnen. De herdenkingsdiensten werden soms in samenwerking met de Gereformeerde kerk gehouden.

Op Mundo nobo. Eerst verbonden met de kerk te 's Gravenhage west, daarna met de classis Batavia, kwam de Gereformeerde kerk op Curaçao na de val van Ned. Indië alleen te staan, en werd zij de eenige gereformeerde kerk op vrijen Nederlandschen grond. Zoo werd haar beteekenis voor de verstrooide, buiten kerkelijk verband geraakte geloofsgenooten groot. Met de Gereformeerden in Zuid- en Noord-Amerika ontstond nauwer band. Met name met de kerken in Zuid-Amerika, geen Nederlanders meer maar stamverwanten, werd aanraking gezocht. In 1942 bracht ds. Muller van de Christian Reformed Church uit de Vereenigde staten een bezoek aan Curaçao. Ds. Kroeze van Curaçao bezocht in 1943 de Gereformeerden in Suriname. Verder had de kerk van Curaçao leden in Venezuela, Columbia, Ecuador. De Gids en de preekenuitgave Leiding en Troost onderhielden het verband met de leden.

De Noord-Amerikaansche troepen brachten een eigen veldprediker mee, ds. W. Rings, die zijn Arubans Annals schreef. 
Joodsch leven. De Joodsche gemeenschap op Curaçao is klein maar belangrijk; er zijn ongeveer 1000 Joden op Curaçao en Aruba. In den heer I. Jesurun Cardozo kreeg dezen kring een bezielend rabbijn, een 40jarigen Amsterdammer, die in 1939 aangekomen is. In de oude Portugeesch-Israelitische gemeente Mikve Israel, gesticht in 1672, was al 15 jaren lang reeds geen Vrijdagavonddienst gehouden, feesten werden weinig in acht genomen, en zelfs huwelijken vaak niet meer in de synagoge gesloten. In den oorlog kwam hierin verbetering. Een kinderkoor maakt den kerkgang aantrekkelijk, en op de scholen wordt aan een 100tal leerlingen Joodsch godsdienstonderwijs gegeven. Het aantal naar de spijswetten levende families neemt toe. De rabbijn geeft sabbathmiddag een godsdienstleergang voor volwassenen. Mikve Israel was gedurende langen tijd het eenige Joodsche blad in het Nederlandsch met Teroenga in Suriname. Er was een studieclub Or Chadas, in 1942 opgericht. Chanoekafeesten werden gevierd. De rabbijn deed mee aan de godsdienstige Curomuitzendingen.

Een jeugdclub Maccabi bracht vooral de kinderen van buitenlandsche Joden samen. Een tooneelgroep van deze vereeniging heeft een geheel in het Hebreeuwsch geschreven blijspel opgevoerd.

De opbloei in deze gemeente kwam van pas, toen het schrikbewind tegen de Joden in Europa steeds hooger en feller oplaaide, en hulp van hier noodig was. In 1941 werd het Joodsch Hulpcomité opgericht, waarin alle Joodsche groepen samenwerkten om vluchtende Joden te helpen.

Zoo werd bijstand verleend aan 86 vluchtelingen, die in deerniswekkenden staat met de Cabo de Hornos aankwamen, eigenlijk bestemd voor Brazilië en Argentinië, maar daar door de bureaucratie en op grond van nieuwe immigratiebepalingen teruggezonden. Omdat zij anders naar Europa zouden worden teruggebracht, nam Curaçao hen op, maar eerst nadat de American Joint Distribution Committee zich tegenover de Nederlandsche regeering in Londen tot borg voor de vergoeding van alle kosten - tot die van drinkwater toe - had gesteld. Eerst waren in een kamp mannen en vrouwen gescheiden; later werd het gezinsverband hersteld. Thans verblijven nog vier van deze families hier; de overige zijn geëmigreerd. Het Joodsche Hulpcomité verstrekte alles.

Dit comité richtte ook een inlichtingendienst in, trad in verbinding met Joodsche vertegenwoordigende lichamen in Nederland en werkt samen met de organisatie van dr. J. Hertz, opperrabijn van het Britsche imperium. 
Het Joodsch Noodfonds 1945 is een andere vorm van materieele hulp. Het werd gesticht door den rabbijn Cardozo, en voldeed aan tallooze aanvragen om hulp uit Nederland: betaalde gebedenboeken, ritualiën, kleeren, voedselpakketten, twee volledige synagoge-ambulances, waarvan een door Morris Cardoze jr. geschonken was.

Eind 1942 werd een comité gessticht, dat in Roxy een protestvergadering hield tegen de uitmoording der Europeesche Joden. Hier spraken de gouverneur en sprekers van alle godsdienstige gezindten. De collecte bracht een ton op, waarvan de helft werd aangeboden aan prinses Juliana voor hulpverleening aan Nederland en de andere helft over buitenlandsche Joodsche organisaties werd verdeeld.

Een enkele maal bezocht een Noord-Amerikaansche leger- en vlootrabbijn Curaçao, en ook op andere wijze werd voor de Joodsche zeelieden en militairen gezorgd.

Behalve Mikve Israel bestaat in Curaçao de Ned. Hervormde Israelitische gemeente Emanu-El, opgericht in 1865. De rabbijn Mortimer Alvarez Correa trad in den oorlog af wegens zijn hoogen leeftijd. Sedert behartigt rabbijn Cardozo ook de belangen dezer gemeenschap. In de eigen kerk wordt nu alleen nog op Grooten Verzoendag dienst gehouden.

$\mathrm{Er}$ is verder een Asjkenazische groep, ongeveer 80 families, uit Roemenië, Polen, Rusland enz.

In de laatste 20 jaren heeft zich een groep van 150 personen op Aruba gevormd. Op de andere eilanden zijn geen Joden, behalve de tijdelijk op Bonaire geïnterneerden van wege hun Duitsche en Oostenrijksche passen.

De Katholieke kerk. Toen de vijand ons land overrompelde, werd het reeds voorgeschreven gebed Pro pace vervangen door dat In tempore belli.In de Meidagen was monseigneur Verriet op de bovenwindsche eilanden, wijlen pater De Bruyn trad op als provicarius apostolicus. Gebedsacties werden gehouden op de scholen en voor volwassenen.

De geestelijken, die met verlof waren, konden niet terugkomen uit het moederland. Andere plaatsen vielen open door overlijden. Het pensionnaat Welgelegen werd opgeheven en het gebouw deed dienst als kazerne. Het parochiewerk bleef doorgaan. Van het jeugdwerk vond vooral de sport aftrek. Op 3 Nov. 1940 werd ter gelegenheid van monseigneur Verriets 60sten verjaardag een sportveld van de Katholieke sportcentrale geopend. Voor de meer ontwikkelde jeugd trad de St. Thomaskring op met een eigen 
clubgebouw. Voor de Surinaamsche jeugd was er de St. Aloysiuskring, met een eigen orgaan Contact.

$R$. K. zorg voor de militairen. Als aalmoezeniers der opgeroepen Curaçaosche schutters trad op pater A. van der Meer O. P.; hij had den militairen rang van majoor. De Noord-Amerikanen brachten hun eigen aalmoezeniers mee. Ten einde de aanraking met deze troepen te vergemakkelijken werden in de kerk van O.L.V. van den Berg Carmel voor Engelsch-sprekenden diensten gehouden en een afdeeling van de in de Vereenigde Staten populaire Holy Name Society opgericht op 27 Jan. 1943.

De verduisteringsmaatregelen maakten de avonddiensten onmogelijk en waren de doodsteek voor de congregaties. Aan den anderen kant werd het geestelijk leven versterkt door nieuwe devoties en congressen. Don Bosco hield ieder jaar zijn welgeslaagde onderwijsdagen. Van de devoties breidde vooral die tot de heilige Philomena zich snel uit onder den grooten promotor daarvan pater V. d. Elsen. Een fraai beeld, gemaakt door Suzanna Nicolaas schonk gouverneur Wouters aan de St. Annakerk. Vermeld dienen enkele inlandsche roepingen bij de Broeders van Brakkeput en de Zusters van Roosendaal.

In Jan. 1942 vierden deze zusters haar eeuwfeest. Soeur Bathilde verzorgde het bij die gelegenheid uitgegeven Gedenkboek. Op de cour van het St. Martinusgesticht werd in tegenwoordigheid van een 1200 personen een H. Mis opgedragen. Een grootsche avond waarop velen het woord voerden, besloot den feestelijken dag.

Een goed jaar tevoren, 19 Nov. 1940, had frater Radulphus, de organisator van het Katholieke onderwijs op Curaçao, zijn halve eeuwfeest gevierd.

In Oct. 1942 vierden de Kruisvaarders van St. Jan hun derde lustrum op Brakkeput.

Vermeld moet het eeuwfeest van het vicariaat eenige maanden eerder. Het 100 jarig bestaan van het St. Martinusgesticht ging in hetzelfde jaar onopgemerkt voorbij.

In de fraai gerestaureerde kerk van Pietermaai werd in Juli 1945 het 75 jarig verblijf van de paters Dominicanen in Curaçao herdacht. Als pauselijke vertegenwoordiger was voor deze gelegenheid overgekomen mons. Paoli Bertoli, zaakgelastigde van den H. Stoel in Haïti en Santo Domingo, met jurisdictie over Puerto rico en de Kleine Antillen. Ook op de andere eilanden werd dit feest gevierd.

De zusters van Schijndel op Santa Rosa herdachten 12 Aug. 1945, dat zij vóór 25 jaar gekomen waren. 
Belangstelling voor geschiedenis. Mede door deze herdenkingen kwam er nieuwe belangstelling voor de kerkgeschiedenis. Van de hand van pater Latour, den lezers van D.W.I.G. wel bekend, zal eerlang een geschiedenis der R.K. kerk in Curaçao verschijnen. Pater M. Brada O. P. gaf in La Union enkele feuilletons op dit gebied. Ook de Amigoe en het nieuwe tijdschrift $L u x$ bevatte meer dan een opstel van geschiedkundigen aard.

Andere feiten. De verscheiden landaarden, Portugezen, Columbianen, Venezolanen en Dominicanen vierden hier hun nationale feesten kerkelijk. Op Curaçao werd de R.K. cathechismus in het Nederlandsch herdrukt. Er werden gelden bijeengebracht voor andere missies. Monseigneur Verriet woonde in Nov. 1942 het Mariacongres in Maracaibo (Venezuela) bij.

De bovenwindsche eilanden bleven geïsoleerd. Aruba en Bonaire waren door de luchtvaart dichterbij gebracht.

Cultuur. De oorlog bracht een hausse van materieele welvaart mee, die het beste blijkt uit de opbrengst der belastingen. De beoefening der kunst bloeide ook.

Vooral was dit het geval met de toonkunst, waarvoor de Curaçaosche kunstkring onder leiding van mr. C. F. Gronemeijer, oud-Gouvernementssecretaris. In 1940 speelde hier de harpist Nikanor Zabaleta en de violist Jascha Haifetz. Carmen werd gegeven te zamen door de Metropolitan opera van New-York en de opera van Chicago. Dat was nog vóór Curaçao in den oorlog werd betrokken. Alexander Brailowski speelde piano. De Ned. pianist Teun Don belandde hier en gaf een concert. Na in Haïti vertoefd te hebben kwam hij terug en stichtte het Curaçaosch conservatorium, dat 1 Juni 1945 werd geopend. Het Lenerkwartet gaf concerten op Curaçao en Aruba.

Max Tak, langs sluiksche wegen den vijand ontkomen, gaf vioolconcerten op Curaçao, maar werd later te Boston aangenomen voor de Ned. radio-uitzendingen. Alexander Uninski gaf een pianoconcert in Roxy.

In 1943 kreeg het Curaçaosche publiek den vermaarden vedelaar Jehudi Menuhin te hooren; tweemaal vertoefde hij in dat jaar daartoe hier.

Een ander bekend pianist, Rudolf Firkusni, wiens naam gedurende den wereldoorlog II op het Westelijk halfrond gegroeid is, bezocht Curaçao in 1944. Van de Zuid-Amerikaansche kunstenaars, die hier kwamen, moeten genoemd de Argentijnsche vio- 
list Ricardo Odnoposoff, en de Venezolaansche pianiste Emma Stoppells.

Een gebeurtenis van waar genot was in 1945 de komst van het duo Feinland. Verder dienen te worden genoemd: de neger-bariton Todd Duncan, Bruna Castagna, beiden uit de Vereenigde Staten, dr. Gaston Valentiy, tandarts op St. Maarten F. G..

Het Curaçaosch Philharmonisch concert bloeide onder leiding van den heer R. W. F. Boskaljon. Reeds eenige maanden vóór den oorlog opgericht, gaf het 21 Dec. 1941 zijn eerste concert, en 20 Juni 1944, toen het vijf jaar bestond, zijn 20ste. Het telt thans ongeveer 43 leden.

De herinnering wordt bewaard aan het Curaçaosch strijkkwartet, opgericht door den luitenant ter zee A .P. Smitt.

De andere eilanden zijn nog niet zoo ver. Op St. Maarten vormde zich met Adriaan van Meerten een niet onverdienstelijk muzikaal trio.

Eenige malen kon er een geslaagde schilder- of teekententoonstelling worden gehouden. Er werd toen veel gekocht, zoodat de interieurs der Curaçaosche woningen ook in dat opzicht veel gewonnen hebben. Zoo is in het bezit van de familie Smeets een schilderij van Nicolaas Joep gekomen, en het St. Elizabeths gasthuis heeft in de verbouwde hal een kleine, zeer kostbare verzameling van oude meesters met een glas-in-lood raam van den genoemden meester.

Curaçao heeft ook zelf schilders. Het is echter de vraag, of allen, die hier in de laatste jaren naar voren zijn getreden, voldoen aan de eischen eener objectieve critiek. Aardig werk is geleverd, door J. C. Pietersz of Alvarez en vooral Guillermo Martis. De eerste kwam uit op de tentoonstelling in San Francisco in 1939. De portrettist Jan van Bergeijk levert werk, dat zeker niet zonder verdienste is. Daarnaast heeft men de Griek Pandellis, die al jaren op Curaçao werkt. Een schilder, die in de oorlogsjaren veel gekocht werd, was Rob Lend. Piet van Leeuwen, de gezaghebber der bovenwindsche eilanden, schildert voor liefhebberij verdienstelijke landschappen, en ds. Alers op Aruba doet dit ook.

Letterkunde. Voor Nederlandsche gedichtenbundels bestond hier nooit veel belangstelling. Eenige landskinderen dichtten in het Spaansch. Zoo Wolfschoon en Corsen, welke laatste ook eenige gedichten in het papiamentsch gaf. P. A. Lauffier, een Curaçaosch politieagent, die eenige verzen in het Nederlandsch schreef, kwam in 1944 onverwacht met een vijftigtal verzen in het Papiamentsch. In Sept. 1940 kwam de fraai uitgegeven periodiek De Stoep voor 
den dag onder redactie van F. J. van der Molen en Luc. Tournier (dr. C. J. H. Engels), Jan Greshoff en H. de Wit. Het zijn meest Europeesche Nederlanders, die inzenden; een enkele maal is het een Curaçaoenaar of Surinamer. Van Tournier verscheen de bundel Kleine Curaçao verzen, die naast enkele mooie verzen veel onrijpe producten bevat van een geest, die ongetwijfeld dichter is.

Hun leesstof zochten de menschen in bladen als het Londensche Vrij Nederland, Knickerbocker, het Curaçaosche Neerlandia, Lux en andere plaatselijke bladen en tijdschriften. Met dit al was er een ernstig tekort aan goede Nederlandsche lectuur. Had het gouverment hier geen taak? Vooral toen in het voorjaar 1945 sir Harry Luke namens de British Council in een lezing had meegedeeld, dat dit lichaam besloten had de Britsche letterkunde op Curaçao te brengen? De smaak voor het goede boek heeft in de oorlogsjaren hier ongetwijfeld geleden, aangewezen als men was op Noord-Amerikaansche „,best-sellers” en „magazines”.

Belangstelling voor de geschiedenis. Over de geschiedenis der R.K. missie werd reeds gesproken. Pater Brenneker gaf in de Amigoe di Curaçao een geschiedenis van Bonaire. In 1941 verscheen een Geschiedenis der Nederlandsche Antillen van de fraters van Tilburg. Ter gelegenheid van den 80sten verjaardag van W. M. Hoyer zag een bundel Geschiedkundige opstellen het licht met bijdragen van de fraters van Tilburg, dr. De la Try Ellis, N. van Meeteren, dr. I. S. Emmanuel, E. Lopez Henriquez.

Kapitein G. Seppen vorschte naar oude krijgskundige verhalen van Curaçao en publiceerde er enkele van. N. van Meeteren schreef zijn Noodlotsdagen over het bestuur van gouverneur Lauffer. Dr. J. C. de Groot deed eenige geschiedkundige artikelen in plaatselijke bladen verschijnen, o. a. over Stuyvesant. Dr. J. Hartog schreef over Journalistiek leven in Curaçao.

Van en over Curaçao. Wetenschappelijke medische publicaties gaven dr. Ph. M. Hartz, dr. A. v.d. Sar, A. v. Meeteren, dr. G. S. van Raalte, dr. A. W. Pot en dr. H. Spitzer. Eerstgenoemde, pathaloog-anatoom in gouvernementsdienst, kreeg een professoraat aan de hoogeschool te Antiquia aangeboden, maar bedankte, onmisbaar als hij hier was. In Maart 1945 deed de Curaçaosche tandarts Debrot een uitvinding, die het mogelijk maakte de tandelooze achterkaak te herstellen.

Een uitvoerig geïllustreerd boek, door $\mathrm{Ph}$. Hanson Hiss geschreven, Netherlans America, is het mooiste foto-album, dat over dit 
gebiedsdeel verschenen is. De tekst is echter dikwijls oppervlakkig en onjuist. Deze schrijver, die in 1942 Curaçao en Suriname bezocht, gaf ook uit, in 1943, Selective Guide to the English literature on the Netherlands West Indies.

Vereenigingen. In Sept 1942 werd opgericht de Curaçaosche vereeniging van opvoeding en onderwijs, in 1943 de Vereeniging Mgr. Nieuwindt, die Lux uitgeeft, en in het algemeen beoogt het cultureele leven onder de Katholieken te bevorderen.

Een Cultuurcentrum. De oude "Inspectie van het onderwijs” werd 1 Mei 1943 ,Departement van onderwijs en volksontwikkeling". Op het Van Walbeeckplein kreeg dit een geheel nieuw gebouw met klankbord, de zoogen. Orpheusschulp. In de gouvernements leeszaal en bibliotheek, in dit gebouw gevestigd, liggen thans 69 bladen ter lezing; de boekerij is nog voor veel verbetering vatbaar.

De gouvernementspersdienst heeft een bescheiden begin gemaakt met een Zuid-Amerikaansche economische bibliotheek op Pietermaai; de Protestansche gemeente te Emmastad opende de Dr. Eykman-bibliotheek, daartoe in staat gesteld door den schout bij nacht C. J. baron van Asbeck, langen tijd Algemeen militair commandant op Curaçao, vooral bedoeld als jeugd-bibliotheek. Het Katholieke jeugdwerk heeft een boekerij in de Conscientiesteeg.

Folklore. De folklore werd in de oorlogsjaren meer en meer naar achteren gedrongen. Een gevolg van de toenemende welvaart? Er werden nog oogstfeesten gevierd op Curaçao en Bonaire. De lintendans, behoorende o. a. tot de ,waterzegening”, die aan de St. Michielsbaai pleegt plaats te vinden, werd ook uitgevoerd bij het bezoek van prinses Juliana.

De Pers. Allereerst moet genoemd de oprichting, reeds in Juni 1940, van de gouvernementspersdienst. Deze bedoelde Curaçao meer bekend te maken met Nederland en de andere gebiedsdeelen, en naar buiten meer bekendheid te geven aan Curaçao. Aan dezen dienst werd toevertrouwd de preventieve censuur op de Curaçaosche bladen, die tot Aug. 1942 heeft bestaan. In hoofdstuk VII van het reeds genoemde Journalistiek leven op Curaçao, vindt men de geschiedenis van de pers op Curaçao van 1792 af. Het werd geschreven bij het 60 jarig bestaan van de Ned. Journalistenkring en het 40 jarig bestaan van de Ned. R.K. journalistenvereeniging. 
Bij het uitbreken van den oorlog was hier één dagblad, Beursen Nieuwsberichten, redacteur J. v. d. Walle, in het Nederlandsch. La Prensa en Boletin-Comercial-Handelsblad, ook dagbladen, verschenen in het Spaansch. Op Aruba had men de kleine Aruba Post.

De Amigoe di Curaçao verscheen destijds tweemaal in de week; redacteur was toen pater Hulsman. 1 Maart 1941 werd deze courant een dagblad. Verder waren er volksbladen als $\mathrm{La} C r u z$ en La Union in het Papiamentsch.

De berichten der Ned. nieuwsdiensten bleven uit; de ter vervanging daarvan aangegane abonnementen op Noord-Amerikaansche agentschappen leverden een tekort aan Ned. nieuws op, waarvoor echter de gouvernementspersdienst nu zorgde. Droevig was, dat „Londen” de Ned. bladen in den vreemde beter met nieuws uit Nederland voorzag dan de Curaçaosche pers.

De genoemde redacteur van Beurs- en Nieuwsberichten ging over naar de gouvernementspersdienst in Suriname; hier werd hij vervangen door H. de Wit. Dr. M. E. Elias van de Curaçaosche gouvernementsvoorlichtingsdienst ging naar de Knickerbocker in New York en later naar Elseviers Weekblad in Amsterdam.

Behalve eenige jeugdblaadjes van scholen enz. moeten als nieuwe bladen genoemd worden Mikve Israel (1940), Leiding en Troost van ds. Kroeze ( 1940), een preekenserie; Ons Kerkblad van ds. Steenstra nam in beteekenis toe. Andere bladen en tijdschriften zijn reeds genoemd.

De Lago en de C.P.I.M. richtten onderscheidenlijk op Aruba Essex Nerws en het rijk geillustreerde maandblad De Passaat. De dames kregen het Voc-blad, de politie het Militair-en Politietijdschrift. Sedert Nov. 1941 hebben de Surinamers Jong Suriname. Dan waren er nog verschillende vereenigings- en sportblaadjes. De drukkerijen waren zoo overbelast, dat het op tijd verschijnen der bladen moeilijkheden opleverden. Het is jammer, dat er - afgescheiden van de Economische Berichten - sedert Juli 1943 het blad van de Gouvernementspersdienst - van overheidswege zoo weinig werd gedaan om de Europeesch Nederlandsche stem te doen hooren.

Vermeld moet worden, dat van particuliere zijde 10.000 exemplaren van een foto van prinses Juliana met haar kinderen werd verspreid, wat een bate van 4500 gulden voor het Prins-BernhardFonds opleverde, en dat in hetzelfde jaar (1941) met medewerking van de onderwijsinspectie een filmpje van het leven der prinsesjes in Canada werd vertoond. 
Later ging de Gouvernementspersdienst op de verschillende eilanden foto's, die de Nederlandsche oorlogsspanning in beeld brachten, tentoonstellen.

De Curaçaosche Persvereeniging zocht aanraking met buitenlandsche journalisten, die Curaçao, en dikwijls ook Aruba, bezochten, waarvan vele artikelen in de buitenlandsche pers het gevolg waren.

Een merkwaardige uitgave was Daily Force, een dagblaadje op tabloïde formaat voor de Noord-Amerikaansche troepen op deze eilanden. Op de reis naar Curaçao ontstond het en van 11 Febr. 1942 werd het gedrukt. De redacteur had zijn kantoor in het gebouw van de Amigoe, die ook het wereldnieuws leverde. Met de beroemde Star \& Stripes was Daily Force eenig in haar soort. Het eindigde zijn bestaan in Aug. 1944.

Mens sana. Veel is er voor de sport gedaan: voetbal, korfbal, honkbal vielen zeer in de smaak. Op het Rif werd een sportveld der R.K. Sportcentrale geopend in Nov. 1940. 31 Jan. 1943 opende de Cur. Bond van lichamelijke ontwikkeling een stadion, waar behalve sportfeesten ook nationale betoogingen werden gehouden. Einde van dat jaar schonk de Koninklijke familie aan dezen bond een ton gouds om in Emmastad een zwembad te bouwen, dat verrezen is op de plantage Rustenburgh. Ook op Aruba werden sportclubs opgericht.

Op St. Michiel kwam een militair zwembad. De Noord-Amerikanen zaten op Jan Thiel, de politie in de Vaersenbaai. Voor de burgerbevolking bleef alleen Port Marie over.

Er kwam een wielerbond, een wandelvereeniging, een aeroclub; ook eenige dames hebben een vliegbrevet.

De Curom. De Curaçaosche Radio Omroepvereeniging, feitelijk een onderneming van de C.P.I.M., stond aanvankelijk onder leiding van A. Kreps. Zij kreeg haar nieuws van de Beurs- en Nieuwsberichten, en toen een ongegrond gerucht wilde, dat dit dagblad proDuitsch was, werd ook elk bericht van een Duitsch succes voor Duitsch-gekleurd uitgekreten, maar het was nu eenmaal de tijd van Duitsche successen. Na twee maanden werd de nieuwsberichtgeving gestaakt. De kern der zaak was, dat het gouvernement niet zorgde voor Nederlandsche berichten, wat in Suriname wel gedaan werd. Toen hierin voorzien was, bedaarden de gemoederen allengs. 31 Maart 1942 kwam er een nieuwe versterkte zender, de Juliana-zender, nog steeds gehuisvest in het Riffort, met de antennes op Groot-Kwartier. De druk, die van overheidswege

West-Indische Gids XXVII 
werd uitgeoefend op de Curom, werd weerstaan, tot zij gouvernementssubsidie aanvaardde. Toen kwam er al spoedig een nieuwe omroepleider in den schrijver van Het wassende water, $\mathrm{H}$. de Man, die in Londen bij Radio-Oranje had gewerkt. Zijn optreden veroorzaakte nieuwe conflicten, maar hij wist op den duur het volk te pakken met zijn uurtjes in het Papiamentsch, zijn dagcommentaren e. d. In Juni 1945 vertrok De Man naar Nederland na met vlijt en energie veel voor de Ned. zaak te hebben gedaan, meer dan een amateur-journalist op zijn plaats zou hebben kunnen doen. Zijn opvolger was de wegens ziekte als gouvernementssecretaris afgetreden mr. C. F. Gronemeijer.

De Curom heeft o. a. goed werk gedaan met de uitzending van groeten, die van Dec. 1944 tot Mei 1945 zeer gewaardeerd zijn. Na Mei 1945 zijn er wekelijksche uitzendingen naar Nederland begonnen. Ook op cultureel gebied doet de Curom goed werk zij geeft lichte en zware muziek, des avonds volksmuziek, ook van Zuid- en Midden-Amerikaanschen aard. Omstreeks Paschen is de Mattheuspassion gegeven. Zondags zenden de verschillende kerken bij beurte uit, en ook in de week worden godsdienstige uurtjes gegeven. Ooggetuigenverslagen van belangrijke gebeurtenissen als het bezoek der Prinses, wedstrijden, Kerstwenschen voor zeelieden, dagelijksche nieuwsberichten, lezingen, zijn hier als elders bekend.

Buitenlandsche Activiteit. De ,consul” is in de Curaçaosche samenleving een figuur van beteekenis. Die van Duitschland en Italië haalden bij het uitbreken van den oorlog hun wapenborden binnen. China kreeg zijn consulairen vertegenwoordiger. Alle proNederlandsche consuls sloten zich aaneen en maakten ook propaganda voor hun eigen zaak, de zaak van het land, dat zij vertegenwoordigden. Het Britsche consulaat kreeg een nieuwen beheerder in E. T. Lambert, thans persattaché op de Britsche ambassade te 's Gravenhage. Gedurende de aanwezigheid van Britsche troepen werd een gestencild blaadje met nieuws uit Britsche bronnen uitgegeven, het News Bulletin, dat bleef bestaan in een oplage van 360 exx. (een der Cur. dagbladen verschijnt in 500 exx. en gratis werd verspreid. Het consulaat verspreide vlugschriften, en voorzag de Openbare leeszaal van verschillende tijdschriften, en verspreidde zelfs boeken.

In Mrt. 1945 bracht sir Harry Luke, hoofdvertegenwoordiger van de British Council, de toezegging van in het Nederlandsch vertaalde Engelsche boeken; hij zorgde ook voor Engelsche nieuwsprenten in de bioscopen. Het Noord-Amerikaansche consulaat, 
in 1944 tot consulaat-generaal verheven, werkte in denzelfden geest het had bovendien een afd. Handel en Voorlichting, die veel belooft voor de toekomst.

Andere consulaten, als Venezuela, San Domingo, Haïti bleven niet achter. De president van laatstgenoemde republiek, dr. Elie Lescot, was het eerste buitenlandsche staatshoofd, dat Curaçao bezocht. Jammer was, dat voor persoonlijk bezoek zooveel moeilijkheden in den weg werden gelegd door verschillende - ook Curaçaosche - vreemdelingendiensten.

Een comité Pour France libre kwam in Juli 1942 tot stand onder voorzitting van den heer Max Henriquez.

Er was veel wisseling in de bezetting der consulaten. Vooral beroepsconsuls plegen niet lang te blijven. Portugal, zoo lang vertegenwoordigd door den heer S. A. L. Maduro, zond in 1943 een beroepsconsul.

Onderwijs. Het onderwijs kreeg het moeilijk. Het aantal leerlingen vermeerde van 15912 in 1939 tot 23327 in 1944, wat een tekort aan leer- en andere hulpmiddelen veroorzaakte, en ook van leerkrachten. Schoolschriften bleken niet te krijgen; leien en griffels evenmin. Dan maar papier gebruikt. Bij gebrek aan boeken begon men met stencilwerk. Later liet de St. Augustinusboekhandel de oude leerboeken fotostatisch herdrukken. De Schroederschool vermenigvuldigde zoo een landkaart in 1000 exx. Voor Spaansch en Fransch ging men Noord-Amerikaansche boeken gebruiken. De komst van een aantal boeken voor de derderangscursus maakte het mogelijk deze opleiding van onderwijskrachten voort te zetten. Daardoor nam het aantal inheemsche onderwijzers toe. Toch kon het tekort niet opgevangen worden, en zoo kwamen er klassen met 50 tot 60 leerlingen. Op Aruba steeg de nood het hoogst. En men kon niet nalaten van nog onbevoegde krachten gebruik te maken.

In het tekort aan schoolruimte kon ook moeilijk voorzien worden. Men behielp zich met zooveel lokalen, als dadelijk noodig waren, en hield rekening met de mogelijkheid van uitbreiding bij het stichten van nieuwe schoolgebouwen.

De inspecteur, nu hoofd van het departement van Onderwijs geworden, was allengs zoo met administratie overladen, dat de inspectie onvoldoende tot haar recht kwam. Het onderwijsbudget beloopt 2.400 .000 gulden, $d$. d. ongeveer $10 \%$ van de geheele begrooting, en dat ondanks de hooge uitgaven voor de landsverdediging.

Het Middelbaar onderwijs, zoo lang begeerd, is er in den oorlog 
gekomen. Er bleken voldoende bevoegde krachten op Curaçao te zijn. Er werd een driejarige middelbare school opgericht, gevestigd in het nieuwe dubbele schoolgebouw aan het Wilhelminaplein Omdat de ruimte spoedig te klein was, trok men in de oude Wilhelminaschool. De A.M.S. leidt leerlingen, in het bezit $\mathrm{v}$ an. het Mulo B-diploma op tot een einddiploma, dat bij Kon. besl. van 1 Oct. 1942 is gelijkgesteld met het einddiploma H.B.S. B en dus toegang geeft tot de faculteiten der wis- en natuurkunde, medicijnen, Delftsche studie en militaire opleiding. Daarnaast leidt de A-afd. op tot de litérair-economische studiën. Spaansch is daarbij een verplicht leervak.

In Oct. 1941 werd een Vereeniging ter behartiging van het Middelbaar onderwijs opgericht.

De school, die den naam „Peter Stuyvesant-college” kreeg, trok ook leerlingen uit Aruba en Suriname. 28 Febr. 1944 heeft prinses Juliana het standbeeld van den naamgever, geschenk van het Algemeen Nederlandsch verbond, onthuld.

Men hoorde ook reeds spreken van Hooger onderwijs. Een plan daartoe werd gemaakt door prof. dr. J. A. C. Fagginger Auer, een Nederlander, hoogleeraar aan de Harvard universiteit. Men leze daarover de Amigoe van 21 Aug. 1943. In Sept hield dr. P. H. Maal in de „Gezelligheid” een pleidooi voor de stichting van een „basis-universiteit”. Er is nog niets van dit alles gekomen. In Aug. 1945 echter diende de gouverneur een voorstel in bij de Staten om een Rechtsschool te stichten, die ,advocaten" zou opleiden, die de titel ,,rechtskundige” zouden voeren. De begrooting is 28000 gulden 's jaars.

Niet alleen Onderwijs kreeg zijn nieuw departementsgebouw, ook de leeszaal en bibliotheek, nog lang niet voldoende voorzien, kreeg een nieuw gebouw, alles onder één dak.

Tot de nieuwigheden op onderwijsgebied behooren de luchtvaartexamens. De missie riep een nijverheidsschool in het leven. De C.P.I.M. stichtte een beroepsschool, die eigen personeel opleidt, die geen schoolgeld vraagt, maar leerlinggeld geeft.

Er kwam een Vereeniging voor opvoeding en onderwijs. Aan de openbare scholen, tot op de bovenwindsche eilanden toe, verrezen oudercommissies.

Veranderde aanblik. Er is veel veranderd in Curaçao. 12 Mei 1940 werd een nieuwe Protestantsche kerk in Emmastad gebouwd in de omgeving van de juist verrezen R.K. kerk van O.L.V. van de berg Carmel.

Op de plaats van het oude Cinelandia, door brand verwoest, 
verrees een nieuw bioscoopgebouw, dat 2 ton gouds kostte en de grootste bezoekerscapaciteit (2200) van heel Caraïbië heeft. Op hetzelfde plein staat de monumentale, maar niet loopende, klok, die de C.P.I.M. aanbood. Haar ontwerper, Gerrit van der Veen, werd in den oorlog door de Duitschers in Nederland om het leven gebracht. Daaraan herinnert de door het gouvernement aangebrachte plaat: ,Ter gedachtenis aan den ontwerper van dit monument Gerrit Jan van der Veen, geboren te Amsterdam 26 Nov. 1902, gevallen als slachtoffer van de Duitsche tyrannie in 1944".

Toen in deze buurt eenige aardige, oud-Hollandsche geveltjes werden vernield door bouwzuchtigen, kwam een commissie tot stand, die, gesteund door het gouvernement, over dergelijke dingen een veto kon uitspreken, een soort monumentszorg in het klein.

Ook op Otrabanda verscheen een nieuwe bioscoop, aan het Molenplein; 21 Febr. 1941 werd die geopend.

Achter hotel Americano werden in de Consciensteeg eenige krotten opgeruimd; ter plaatse zijn thans de vicariaatsdrukkerij met redactie en administratie van de Amigoe di Curaçao gevestigd, en ook de reeds genoemde bisschoppelijke nijverheidsschool, tot deze in April 1945 een eigen gebouw kreeg.

Op den weg naar Welgelegen is tot dicht bij het pensionaat gebouwd; aan de Pundazijde tot Mari Pompoen, Salina, den berg van Pietermaai, Berg Carmel-weg (Parera); in de buitendistricten bij Zeelandia, Mahaai, Van Engelen en Dominguito.

Op het gebied van den wegenbouw werd veel gedaan. Tot Westpunt kan men gemakkelijk komen zonder de veeren van zijn auto te breken. Op een harer tochten sprak prinses Juliana een bijzonder woord van lof over de Curaçaosche wegen.

Ook op Aruba werd veel gebouwd: het nieuwe vliegveld met stationsgebouw, het Strand Hotel (Nov. '43, een groot weelderig hotel, verreweg het beste van alle Curaçaosche eilanden), clubgebouwen, de prinses Margriet-kazerne, de Julianaschool in Oranjestad.Het wegennet werd mede hier verbeterd.Politieposten, brandweergarages, nieuwe gevangenissen verrezen hier en op St. Maarten.

Op Bonaire bouwde de missie met medewerking van het gouvernement het St. Franciscushospitaal, dat in Juni 1944 werd geopend.

Nieuwe telefooncentrales kwamen er op Curaçao en Aruba; dat op Curaçao is automatisch, en heeft 1300 aansluitingen.

Mahaai met Van Engelen zou men een ,residential section" 
kunnen noemen. Evenals op Parera staan daar fraaie landhuizen. Van daar is er een busverbinding met de stad.

Radiotelefonische verbindingen kwamen in den oorlog tot stand met New-York, Suriname en de eilanden onderling, het laatst in Sept. 1945 de verbinding Curaçao-St. Maarten; kosten 1 gulden 50 cent per minuut.

Saba kreeg een radiobaken ten dienste van het vliegverkeer.

Op Curaçao verrees een groot postkantoor. Curaçao wacht nog op de voorziening in deze dringende behoefte.

Hato krijgt een nieuw stationsgebouw, dat 700.000 gulden moet kosten.

Zoo is er ondanks een bouwverbod geweldig gebouwd. Woonhuizen van 50.000 gulden zijn geen uitzonderingen, evenmin als verkoop van vóór den oorlog gebouwde huizen met $250 \%$ winst.

Uitbreidingsplannen. Reeds vóór den oorlog bleken op Curaçao en Aruba uitbreidingsplannen noodig, maar veel materiaal was niet tijdig uit Nederland aangekomen. Nu zijn zij gereed, maar nog niet bekend. Zij moeten nog in de Staten aan de orde komen.

Volkswoningbouw. Er is nijpende woningnood geweest. Op Domi werd een heel gezin in een hol aangetroffen. De huurprijzen stegen zoo, dat in een rustige buurt in de stad voor 150 gulden in de maand niets of weinig te krijgen was. Menschen in de salarisklasse van 4000 tot 7500 gulden waren niet in staat de gevraagde huurprijzen te betalen binnen de grenzen van hetgeen op het budget daarvoor mag besteed worden. Met de arbeidersklasse was het nog erger. De missie was allang begonnen met volkswoningbouw en in den oorlog is de overheid op dezen weg gevolgd. Eerst kwamen er 11 proefwoningen op Mundo Nobo, en er volgden 25; op de Salina bouwde Openbare werken 25 huizen; op Steenrijk komen er 84 enz.

Op Aruba zijn in Oranjestad 40 in San Nicolaas 60 woningen gebouwd; in totaal op Aruba 192 volkswoningen.

Ter bekostiging van dezen bouw werd in 1943 een leening van 1 millioen gulden uitgeschreven. Voor een grootere leening waren de Staten niet te vinden. Tot voor 17 millioen gulden werd op deze leening ingeteekend.

Hoeveel woningen er in het geheel zullen komen, staat nog niet vast. Wat er gekomen is, is een druppel in de emmer.

De huisjes zijn over het algemeen een succes. Er zijn 6 standaardtypen met 1, 2 of 3 slaapkamers. Een doodsch stratenbeeld wordt vermeden. De huur is 10 tot 35 gulden per jaar. 
De rioleering is nog niet wat zij wezen moet. Vele woningen missen de meest primitieve sanitaire inrichtingen. In 1945 is voor rioolbouw 300.000 gulden uitgetrokken; op Steenrijk is een fabriek ingericht, waar rioolbuizen worden gemaakt.

Verkeer. De schipbrug op Curaçao is nog een sta-in-den-weg. De heeren Stuyvenberg en Van Drimmelen ontwierpen een zinkertunnel, waarvan de kosten op 5 millioen begroot zijn.

Op het gebied van het verkeerswezen is een tweede vraagstuk, dat oplossing vraagt, dat der verbindingen tusschen verschillende stads- en eilandsdeelen. De zoogenaamde volkstaxi's voldeden niet aan de eischen van regelmaat. Het gouvernement heeft met eigen bussen vaste lijnen geopend; het $A$ utobus Bedrijf $C$ uraçao kwam tot stand. Het gouvernement nam voor 249.000 gulden deel in het tot 250.000 gulden volgestorte kapitaal van 1 millioen gulden. Een garage verrees op Saliña. Het bedrijf was winstgevend. $\mathrm{Na}$ afschrijving kon over het eerste jaar 100.000 gulden gereserveerd worden en $10 \%$ dividend uitgekeerd worden.

Er is een lijn om het Schottegat, een naar Santa Rosa, naar Santa Marie, Charo en Mundo Nobo, Julianadorp en Jan Doret. Door gebrek aan materiaal is er nog geen zekerheid van vervoer voor het publiek. Om 7 uur des avonds houden de ritten op.

Economische toestand. Curaçao was en bleef aangewezen op de dollar. Zelfs Surinaamsche firma's eischten van Curaçao betaling in dollars. In Nov. 1941 werden maatregelen genomen om de invoer uit de dollarlanden, waaronder Canada, te beperken. De Nederlandsche regering stelde de koers van de Curaçaosche gulden, evenals die van de Ned.-Indische, tegenover het pondsterling vast op 7.60. De Curaçaosche bank had de koers van de dollar inmiddels al vastgesteld op 1.875. Het gouvernement vroeg aan de regeering in Londen om maatregelen, opdat het sterlingtegoed daar onbeperkt in dollars te New York zou kunnen worden omgezet tegen een koers van omstreeks 4 . Het pondentegoed van $\mathrm{Cu}-$ raçao zou immers steeds stijgen, omdat de C.P.I.M. uit Londen werd gefinancierd, maar van den anderen kant moest Curaçao, van het moederland afgesloten, steeds meer uit de dollarlanden in de omgeving gaan betrekken voor zijn huishouding. Voor bestellingen in Engeland ontbrak de noodige scheepsruimte.

Op 24 Juli 1940 had de Nederlandsche regeering reeds een monetaire overeenkomst met het Britsche rijk gesloten, waarbij de Curaçaosche bank tegen tegoedschrijving in ponden, welke zij voor het grootste deel niet onmiddellijk in dollars kon omzetten, 
toch de alhier gevestigde oliemaatschappijen, tot de Shellgroep behoorende, van kasmiddelen voorziet, evenals zij dit zou doen met aanverwante bedrijven en ondernemingen. M. a. w. Curaçao gaf aan Engeland een crediet tot na den oorlog voor kosten, welke alhier aan het raffinageproces verbonden waren. Intusschen werd in het Britsche rijk de dollarnood steeds nijpender. Dies werd besloten, dat maandelijks over een half millioen dollar ten laste van het pondensaldo van de Curaçaosche bank zou kunnen worden beschikt. Bij dit halve millioen kwamen nog de eigen dollarinkomsten, voornamelijk de locale kosten van de Lago op Aruba. Toch was dit alles nog niet voldoende om alle behoeften uit de dollarlanden te dekken. Een beperking van den invoer uit deze landen was dus noodig en leidde tot het quotumstelsel. Het sterlinggebied, dat feitelijk alleen het Britsche rijk, met uitzondering van Canada en New Foundland omvat, kon niet voldoende goederen en diensten leveren. Hierdoor steeg het pondenbezit van de Curaçaosche bank aanzienlijk. Daarbij kwam nog, dat, behalve de financiering van de C.P.I.M., ook de financiering van de K.N.S.M., de Koninklijke Nederlandsche Stoombootmaatschappij in Londen geschiedde. De vrachtprijzen echter konden grootendeels slechts in dollars betaald worden.

In Oct. 1942 werd toen door de Nederlandsche regeering de verplichting, die de Britsche regeering op zich genomen had, nl. om een half millioen dollars per maand over te maken, overgenomen. Tevens verhoogde de Ned. regeering het bedrag tot 600.000 dollars, terwijl zij ook het tegoed aan ponden van de Curaçaosche bank bij de Bank van Engeland, voor zoover 1 millioen pond te boven gaande, zou overnemen tegen goud of dollars tot ten hoogste 20 millioen gulden jaarlijks. Herhaalde besprekingen zijn gevoerd en bij het sluiten van dit artikel is daaraan nog niet een einde gekomen. Curaçao heeft op monetair-economisch gebied voor groote moeilijkheden gestaan.

Door tekort aan beschikbare dollars moest de handel zich beperken. Einde 1941 is een Handelsregister ingesteld. De INCU is reeds genoemd. Curaçao moest aan de Vereenigde staten opgeven wat het dacht noodig te hebben, ,,future requirements”. Hierbij moest getracht worden zoo veel mogelijk uit andere landen te betrekken. Vandaar een omzwaai van den handel naar ZuidAmerika. De Argentijnsche goederen met name bleken van goede hoedanigheid te zijn, maar in verfijnde goederen kan deze markt de Europeesche nog niet verdringen. 
Schoenermaatschappijen. Onder leiding van de Curaçaosche Handelsmaatschappij werd in Nov. 1942 opgericht de N.V. Maatschappij tot exploitiatie van schoeners. Daarop volgde de WestIndische schoenermaatschappij, de „Wismij”, in 1943. De firma Martijn opende een dienst op Haïti. Zoo bloeide de oude schoenervaart bij gebrek aan motor- en stoomschepen, in het geheele Caraïbische gebied. Bonaire deelde in de algemeene opleving. Toch is de verbinding tusschen de op elkaar aangewezen eilanden nog niet wat zij wezen moet.

Een Cubaansche varende tentoonstelling, die eenige dagen in de haven van Curaçao lag, deed velen verbaasd staan over de voortbrengselen van dit eiland.

Als contrapunt van de INCU werd in New York de Neder-

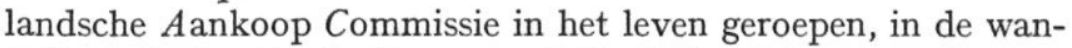
deling ,,de Purchasing" genoemd. Het bijkantoor op Aruba van de INCU kon rechtstreeks met de N.A.C. in verbinding treden.

In 1943, toen de strijd het heetst was, was er veel meer aanbod van lading in Amerika dan scheepsruimte beschikbaar was. Toen heeft Curaçao even in de moeilijkheid gezeten. Gemiddeld werd door de INCU jaarlijks voor 2 millioen via de N.A.C. ingekocht.

De „handel” op Curaçao was weinig te spreken over de groote overheidsbemoeienis. Dit leidde ertoe, dat E.C. Martijn naast de Kamer van Koophandel, die wel eens te weinig voortvarend was, een Vereeniging voor den Handel oprichtte. Op Aruba herrees de Handelsvereeniging.

Nieuwe industrieën. De C.P.I.M. kreeg een vatenfabriek, die 8 Mei 1940 uit Nederland verscheept was. De oprichting moest wachten, tot de uit Nederland ontsnapte directeur van Van Leers Vereenigde fabrieken zich daaraan wijden kon. De vuilnisblikken, die deze fabriek een tijdlang leverde, bleken niet bestand te zijn tegen de wijze, waarop de Reinigingsdienst die ledigde.

Belangrijker was een verzoolinrichting voor autobanden, onderdeel van Van Leers Vereenigde fabrieken, die in Sept. 1944, toen ondanks de overheidsmaatregelen de bandennood zeer hoog gestegen was, geopend werd en goed werk gedaan heeft.

Op het Rif kwam een Pepsi Cola fabriek, bij de Saliña een limonadefabriek tot stand; op Santa Maria een steenfabriek van den Arubaan Oduber, waarvoor de uitrusting uit Brazilië kwam. Deze fabriek verwerkte inlandsch materiaal, gruis, tot baksteenen, dakpannen enz., en drukte zoo de bouwkosten.

Op Aruba werd een nieuwe goudmaatschappij opgericht. 
De economische toestand der bovenwindsche eilanden bleef ongunstig. Tegenover ongeveer een half millioen aan uitgaven op de begrooting stonden nagenoeg geen inkomsten. Toen de verbinding met deze eilanden in 1942 ten slotte geheel ophield, een tijdlang heeft het gouvernement met twee schoeners de bevoorrading van Puerto Rico uit doen plaats vinden. Het particulier initiatief kwam later met een schoenerdienst tusschen Curaçao en Sint Maarten. In 1944 kwam er een stoombootverbinding, waarvan het gouvernement elke reis met 10.000 gulden steunde. De K.L.M. opende een luchtlijn op St. Maarten.

Hier volgen de cijfers van de waarde van invoer en uitvoer gedurende den oorlog:

$$
\begin{array}{llcl}
\multicolumn{2}{c}{\text { Invoer }} & \multicolumn{2}{c}{\text { Uitvoer }} \\
\text { Curaçao } & \text { Aruba } & \text { Curaçao } & \text { Aruba }
\end{array}
$$

1940: 121.160.576.- 135.680.772.- 123.813.984.- 127.327.827.1941: 126.174.849.- 173.519.308.- 140.825.586.- 205.518.183.1942: 134.873.292.- 135.366.236.- 95.544.061.- 118.067.941.1943: 163.708.216.- 180.084.779.- 108.969.146.- 189.094.454.1944: 175.973.594.- 208.318.946.- 135.160.040.- 162.142.490.-

Buiten de petroleumproducten is de uitvoer onbeteekenend, vergeleken met den invoer: $51 / 2$ millioen tegenover bijna 100 millioen. De uitvoer bestaat hoofdzakelijk uit eerst van elders ingevoerde goederen. Volgens Economische Berichten bedroeg de uitvoerwaarde van de voornaamste eigen producten in 1943:

aloë 414.577.- ; fosfaat 17.144.-; huiden en vellen 62.912.-; zout 92.723.-; stroohoeden 38.371.-.

Economisch is Curaçao afhankelijk gebleven van de groote olie-industrieën. Steeds minder jonge mannen zochten een werkkring in de kleine nijverheid en den landbouw.

Suriname's opbouw, in 1944 door Surinamers hier en ginds opgericht, heeft de invoer van citrusproducten van Suriname in Curaçao terhandgenomen.

Middelpunt van luchtverkeer is Curaçao in den oorlog geworden tusschen Noord-en Zuid-Amerika, een centrum in Caraïbië, vooral toen het in 1942 niet meer denkbeeldige duikbootgevaar en andere gebeurtenissen schepen uit de vaart deed nemen. Ook voor binnenlandsch verkeer deed de K.L.M. goede diensten. Thans vliegen maandelijks een 1300 personen op de lijn Curaçao-Aruba, 300 op de lijn Curaçao -Bonaire. En dan de luchtpost. Einde 1944 vervoerde de K.L.M. 13 maal zooveel passagiers, 40 maal zooveel 
vracht en 120 maal zooveel luchtpost als in 1935. Versche groenten worden enkele malen in de week uit Miami in de Vereenigde staten per vliegtuig ingevoerd. Dagelijks worden op Curaçao versche bloemen verkocht, uit Jamaica en Venezuela overgebracht.

Ook de $P$ an $A$ merican $A$ irways vliegt tusschen Aruba en Curaçao. De opening der Linea Aeropostal Venezolana staat geopend te worden.

De Snip, die in 1934 van Amsterdam naar Curaçao vloog, doet nog steeds dienst.

Eind Mei 1940 kwamen er twee nieuwe DC-5's aan: Wakago en Zonvogel, die in 1941 naar de Oost gingen. De Parkiet verongelukte in Aug. 1942 boven Trinidad in het oerwoud, het eerste ongeluk van de K.L.M. in 7 jaar, tevens het eenige van beteekenis.

In 1943 kwamen er 2 Loadstars bij de luchtvloot en in 1944 nog 2 Lockheeds, klein maar nuttig.

Reeds tegen Sept. 1940 was een plan gemaakt voor een rechtstreeksche luchtverbinding tusschen Amsterdam en Curaçao over Lissabon, Casa Blanca, Porto Praia en Paramaribo, die 3 dagen duren zou.

Dank zij den bloei van de bauxietnijverheid in Suriname vervoerde de K.L.M. in 1940 tusschen de beide West-Indische gebied deelen reeds viermaal zooveel passagiers als in het voorafgaande jaar.

Geen der K.L.M. directeuren was in 1940 uit Nederland ontsnapt, en daarom werd de directie van de K.N.I.L.M. te Batavia belast met de directie van de West-Indische K.L.M. Dat duurde tot Sept. 1943, toen West-Indië onder een door de regeering aangewezen directie te Londen kwam.

De volgende nieuwe diensten werden geopend:

19 Aug. 1941 op Jamaica, met aansluiting op de P.A.A. naar Miami. Eerst eenmaal, in Oct. 1941 tweemaal 's weeks;

17 Aug. 1943 rechtstreeks op Miami, met aansluiting op La Guayra;

3 Dec. 1943 op St. Maarten; een veertiendaagsche dienst.

Hato is een volledig uitgeruste technische vliegbasis geworden.

Gebeurtenissen. Bekende Curaçaoenaars stierven in deze 5 jaren: in 1942 de postdirecteur-leider van de hoedenvlechtnijverheid Haim Cohen Henriquez, in 1943 het lid van den Raad van bestuur Jossy Cohen Henriquez, mr. De Haseth Evertsz stierf in Nederland, dr. W. H. Winkel. John Eman, de Arubaansche bankiers; verschillende paters, fraters en soeurs. 
Feestelijke gelegenheden waren: het 70 jarig bestaan van de societeit De Gezelligheid, het halve eeuwfeest van dokter Gaerste's doctoraat, het 45 jarig regeeringsjubileum van de Koningin, de geboorte van prinses Margriet, het feest van de milliardste barrel bij de Lago.

In Mei 1941 werd een groot internationaal Rotary congres op Curaçao gehouden, in 1945 een op Aruba.

September 1942 gaf een verkeerstelling op Curaçao te zien. De resultaten hiervan zijn echter nooit bekendgemaakt.

$\mathrm{Er}$ is een tijd geweest, dat het zilvergeld werd opgepot. Geen gulden was te krijgen, en er moesten muntbiljetten worden in omloop gebracht, van één gulden in 1942, in 1943 van een rijksdaalder. Zij werden gedrukt bij de American Banknote Company. In den loop van 1944 raakten ook de kwartjes en dubbeltjes op; de nieuwe vervingen het opschrift „Kolonie Curaçao” door „Munt van Curaçao" en , ,1/4 G". in plaats van ,25 cents". Het maaksel bleek echter minder deugdelijk dan het oude Nederlandsche, want na eenige maanden werden ze geel. 17 Januari 1945 werd het besluit, dat de Curaçaosche gulden los staat van de Nederlandsche, bekend gemaakt.

Een groote gebeurtenis was de verschijning van een telefoongids in Jan. 1945 ter vervanging van de sedert jaren onbruikbaar geworden gids.

Onder de nieuwe winkels, die geopend werden, moeten die op het gebied van den juweelenverkoop genoemd worden, die in mooie panden verrezen. In Juli 1945 werd de Coöperatieve $C$ onsumentenvereeniging $C$ uraçao met ongeveer 700 leden opgericht.

Reeds werd gesproken van het nieuwe onderzoek naar goud op Aruba. De oud-directeur der C.P.I.M. Van Nijmegen Schoonegevel had hier belangstelling voor. Een Canadeesche onderneming liet onderzoekingen doen, en dit leidde tot de oprichting der Maatschappij tot exploitatie van goudmijnen op Aruba, gevestigd op Curaçao.

Een poging van het gouvernement om den tijd met één uur te vervroegen, in Maart 1942 gedaan, wekte zooveel verzet op, dat de zaak bleef rusten. De bedoeling was om aldus op de verduistering een uur te winnen voor productieve tijdsbesteeding.

Een andere storm stak eenige maanden later op, toen verteld werd, dat eenige praktizijns te veel honorarium hadden gevraagd. De zaak werd echter vergeten.

Enkele malen kwamen stakingen voor; de autohandelaren, de bakkers, de bootwerkers, zelfs.... de gevangenen, hebben 
in den loop dezer jaren gestaakt. Maar het duurde nooit lang. De bootwerkersstaking heeft geleid tot de indiening van een ,stuwadoorswet".

De Limburgers vonden elkaar in een Limburgsche vereeniging, die bij de bevrijding van Maastricht die stad een groet zond.

Aan verschillende internationale conferenties nam Curaçao deel. Die te San Francisco werd bijgewoond door den Statenvoorzitter Sprockel. Dokter Arends van Aruba vertegenwoordigde Curaçao op de Quarantaineconferentie te Washington; ook enkele andere medische conferenties woonde deze bij. De conferentie te Philadelphia in April 1944 werd voor West-Indië bijgewoond door den heer F. A. Vromans en den heer F. H. R. Lim Apo van Suriname.

Enkele dagen geleden kwamen de eerste verlofgangers van 1940 van de C.P.I.M. terug om hun werk te hervatten. $\mathrm{Zij}$ kenden ons eiland niet meer.

Antilla stond in brand in 1940. Die brand heeft de zes eilanden van Curaçao niet onberoerd gelaten. Er is veel veranderd, maar Curaçao is er voor het Koninkrijk des te kostbaarder door geworden.

Toen Curaçao drie eeuwen met Nederland verbonden was geweest, werd in de oude Fortmuur een steen gemetseld met een inschrift, dat de eenheid van het Rijk staafde. Die eenheid wordt op Curaçao nog steeds beseft. Misschien, dat de oorlog ten gevolge zal hebben, dat het moederland, zijn overheidsorganen en zijn bevolking die aandacht aan Curaçao zullen gaan schenken, die dit verdient, van rechtswege, maar ook om wat het beteekent voor het gemeenebest. 